$$
\text { DOE/IE } / 10574-T 2
$$

DOE/IE/10574--T2

DE90 008795

\title{
RADAR IMAGERY INTERPRETATION TO PROVIDE INFORMATION ABOUT SEVERAL GEOTHERMAL STTES IN THE PHILIPPINES
}

ARCI TR O701-102

November 17,1988

prepared by

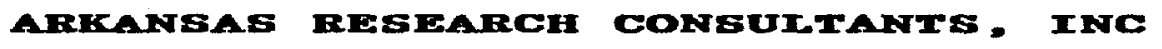

\section{DISCLAIMER}

This report was prepared as an account of work sponsored by an agency of the United States Government. Neither the United States Government nor any agency thereof, nor any of their employees, makes any warranty, express or implied, or assumes any legal liability or responsibility for the accuracy, completeness, or usefulness of any information, apparatus, product, or process disclosed, or represents that its use would not infringe privately owned rights. Reference herein to any specific commercial product, process, or service by trade name, trademark, manufacturer, or otherwise does not necessarily constitute or imply its endorsement, recom7 mendation, or favoring by the United States Government or any agency thereof. The views and opinions of authors expressed herein do not necessarily state or reflect those of the United States Government or any agency thereof. 


\section{DISCLAIMER}

This report was prepared as an account of work sponsored by an agency of the United States Government. Neither the United States Government nor any agency Thereof, nor any of their employees, makes any warranty, express or implied, or assumes any legal liability or responsibility for the accuracy, completeness, or usefulness of any information, apparatus, product, or process disclosed, or represents that its use would not infringe privately owned rights. Reference herein to any specific commercial product, process, or service by trade name, trademark, manufacturer, or otherwise does not necessarily constitute or imply its endorsement, recommendation, or favoring by the United States Government or any agency thereof. The views and opinions of authors expressed herein do not necessarily state or reflect those of the United States Government or any agency thereof. 


\section{DISCLAIMER}

Portions of this document may be illegible in electronic image products. Images are produced from the best available original document. 


\section{PREFACE}

\section{INTRODUCTION}

Arkansas Research Consultants, Inc. (ARCI), conducted an extensive imaging radar survey of selected petroleum and geothermal sites in the Republic of the Philippines. The effort was supported by the United States Department of Energy (DOE), Grant Number DE-FG01-86IE10574.A000.

\section{OAJECTIVES}

The primary objectives of this work were (1) to further the goals of international energy development by helping the Philippine's Government improve its understanding of its energy potential, (2) to advance the economic and energy development of the Philippines and, (3) to increase the world's oil supply base. Secondary objectives were (1) to teach scientists and engineers in the Republic of the Philippines the fundamentals of radar image interpretation, and (2) to provide them with a data base for their continued research and analysis.

\section{SCOPE}

The work conducted was limited to acquiring SAR (synthetic aperture radar) data which included four potential petroleum resource basins and three areas of geothermal resources in the Republic of the Philippines, to interpreting the data acquired for hydrocarbon or geothermal potential, and to ranking the potential of various prospects identified. 
L

U

U

U

L

,

b

,

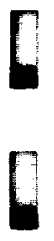

[

[

[

[

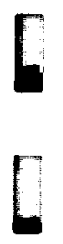

E 


\section{EXFCUTIVE SUMMARY}

This Executive Summary relates the essential aspects of the work conducted for geothermal site evaluation reported here. The petroleum basin investigation is reported in a separate document ${ }^{1}$. A separate report has also been prepared as a comprehensive Executive Summary for a more detailed summarization of the hydrocarbon analysis. ${ }^{2}$

As with most nations of the world, the Republic of the Philippines is intensely interested in the identification, development, and conservation of natural resources. In keeping with this, the Government of the Philippines has recently completed a nation-wide sedimentary basin evaluation program to assess hydrocarbon potential and assist in future exploration activities. This study was directed by the Philippine Bureau of Energy Development (BED) with a significant portion of the work performed by the Philippine National Oil Company Exploration Corporation (PNOC EC). Since this work was completed, the BED has been reorganized and is now known as the Office of Energy Affairs (OEA).

This program of collection and interpretation of the radar imagery was designed to augment and complement the existing data base prepared by BED and PNOC EC. Geothermal and hydrocarbon sites were selected through the cooperative efforts of BED and PNOC EC scientific personnel. The primary objective of the project was to further the goals of international energy development by aiding the Republic of the Philippines in the assessment of potential geothermal and petroleum prospects within the areas imaged. Secondary goals were to assist the Republic of the Philippines in utilizing state-of-the-art radar remote sensing technology for resource exploration, and to train key Philippines scientists in the use of imaging radar data.

1 ARCI, 1988, Radar Imagery Interpretation to Assess the Hydrocarbon Potential of Four Sites in the Philippines, ARCI TR 8701-101, Arkansas Research Consultants, Inc., November 17, 1988.

2 ARCI, 1988, Radar Imagery Interpretation to Assess the Hydrocarbon Potential of Four Sites in the Philippines: Executive Summary, ARCI TR 8701-103, Arkansas Research Consultants, Inc., November 17, 1988. 
Because radar provides its own source of illumination, radar images can be produced that preferentially highlight geologic structure and surface detail. Radar images so constructed provide unique information about the local geology which may not be available from other sources. Such information is needed in the Republic of the Philippines because although the region has been extensively mapped via conventional techniques, large uncertainties in the petroleum resource potential of the area still exist.

Radar's unique capabilities include:

* All weather, day-night operation

* Control of look direction and look angle for improved geological interpretation

* Wide areal coverage-synoptic view

* High resolution comparable with most remote sensing systems

* Stereo capability allows rapid formulation of geologic models

* Sensitivity to vegetation at shorter wavelengths

* Terrain texture discrimination in non-vegetated regions

* Digital capability for image enhancement and multi-sensor integration

* Radar mosaic provides an accurate base map

\section{DATA ACQUTRED}

Radar imagery covering roughly $60,000 \mathrm{~km}^{2}$ was acquired. These data were collected by Intera Technology, Inc., under subcontract from ARCI. ARCI provided mission planning and quality assurance for the program. Complete stereo coverage of five different regions was acquired. Within these five sites, the following seven different sets of data were collected, including three for geothermal evaluation and four for hydrocarbon interpretation. 
Geothermel siter

* Mt. Apo, Mindanao

* North Negros Island

* South Negros Island

Hracocarbon stter

* Bondoc Peninsula

* Cotabato Basin, Mindanao

* Mindoro Island

* Cebu Island

DATA PRODUCED

The final data products were (1) negative film and positive prints of each of 34 flight line strips, (2) computer compatible tapes (CCT) of each image strip, and (3) negative film and positive prints of radar mosaics of four petroleum sites at 1:250,000 scale. The Intera STAR-1 imaging radar system used to acquire these data operated at X-band, $\mathrm{HH}$-polarization, with $12 \mathrm{~m}$ resolution. The final data set represents one of the best examples of radar imagery for resource exploration available anywhere.

Interpretive data products produced include (1) geologic maps, (2) lineament maps, and (3) prospect evaluations. Development of geologic maps and prospect evaluations included extensive use of surface and subsurface data furnished by BED and PNOC EC. Thus, the final evaluation is a synthesis of all data available rather than simply that obtainable from the radar imagery itself. This is perhaps the most significant aspect of the program in that it demonstrates the use of radar as a sensor in an integrated program for geothermal and hydrocarbon exploration. The imagery acquired is an excellent source of data that may be used to refine exploration strategy and define areas for more detailed investigation by ground survey and seismic data acquisition. The image analysis shows numerous areas of agreement with prospects developed from other data 
sources such as field and geophysical surveys. In addition, a considerable number of structures and prospects were discovered, particularly in areas where other data sources were unavailable.

\section{SUmmarex}

This synthesis of all available data shows radar imagery to be an excellent survey tool in an integrated multilevel exploration. The radar by itself may be used to guide acquisition of more detailed data and develop a general exploration strategy. Where other survey data such as photography or LANDSAT are available, the unique response and illumination enhancement of surface structure obtainable with radar is seen to provide additional data complementary to other survey imagery.

Important new prospects and prospect areas have been identified which will provide a focus for further follow-up field and geophysical studies.

Faults and fractures that transect a geothermal reservoir may be regarded as channelways or main trunklines of a geothermal plumbing system. Therefore, a clearer picture of the regional fault/fracture patterns provided by radar interpretation could prove useful in determining permeability controls.

Ceotherinal Prosapecte

* Mt Apo Geothermal Prospect - Analysis of the radar data has led to identification of a previously unmapped east-trending fault system, and recognition of a dominant east and northwest fault system in the Mt. Talomo region where the faulting was previously believed to be radial.

* North and South Negros Geothermal Prospects - Recognition of regional fault patterns mapped from radar will be of significant value in the planning phase for future exploratory drilling. 


\section{HIGEIIGHTS}

* The radar data and this project have significantly improved the knowledge of stratigraphy and structure, and in many cases have provided data for updating existing geologic maps.

* The radar geologic maps produced, while important by themselves, can be used to complement existing geoscience data and can provide new map products tailored to support exploration activities.

* An important aspect of radar investigations is that reconnaissance radar images facilitate field work in remote and impassable areas.

* The baseline survey and interpretation were conducted at a scale of $1: 250,000$, but the data support increasing the scale to $1: 50,000$.

* A training course on radar interpretation and SAR fundamentals has been provided to Philippines geoscientists, and they have become enthusiastic in the potential application of using radar images for this and other important investigations such as land cover mapping (forestry or other vegetation covers/, land use mapping, hydrology, and ground-water exploration.

\section{RECOMMENDATIONS}

* Because the imaging radar program was designed for hydrocarbon exploration in moderate relief areas, excessive radar shadow occurred in some local areas. Therefore, the Negros and Mt. Apo geothermal sites should be reflown to obtain multiple-look direction radar imagery in order to obtain complete, shadow-free, stereo coverage.

* Additional radar imagery should be acquired over a much larger region of the Philippines, especially within those areas where radar can contribute significant data to the development of an integrated exploration strategy for geothermal resources. 
* Radar also should be used to explore for other natural and non-renewable resources, in addition to geothermal potential. 


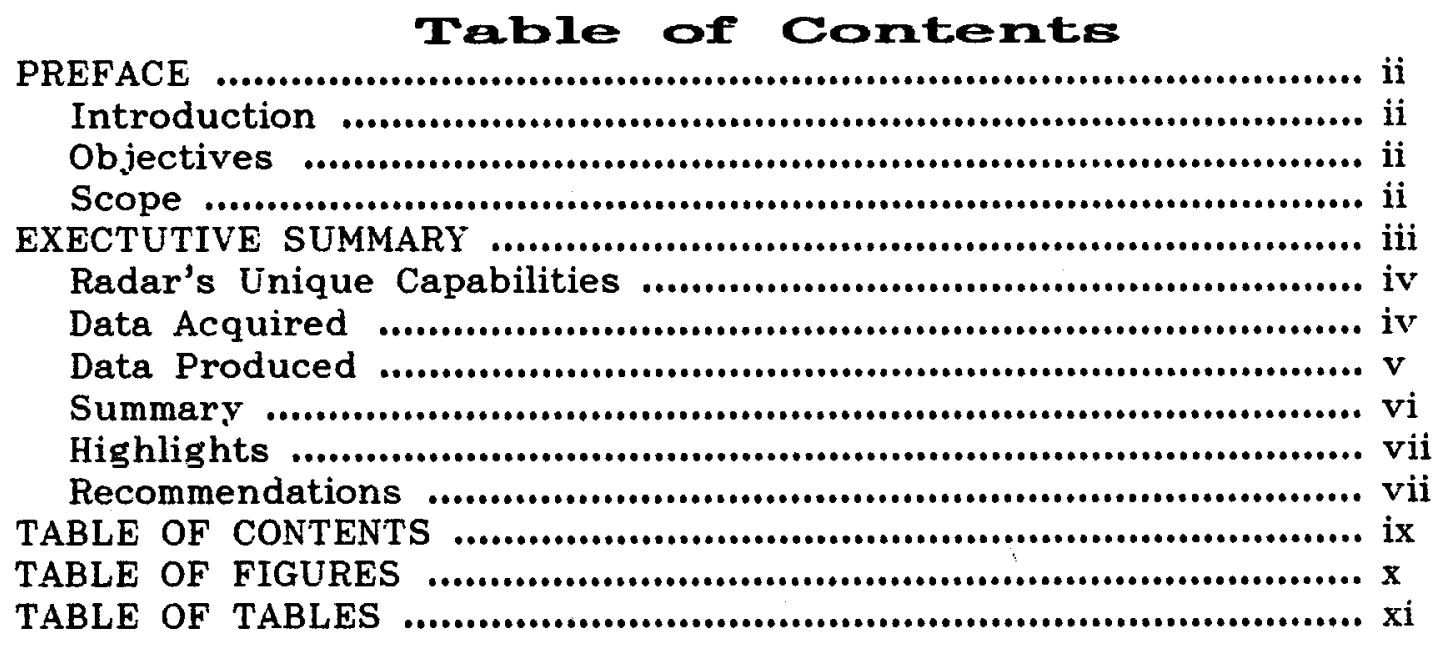

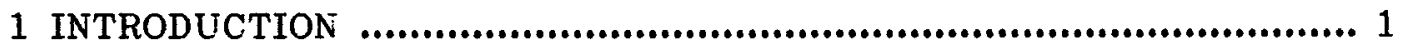

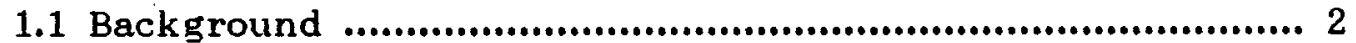

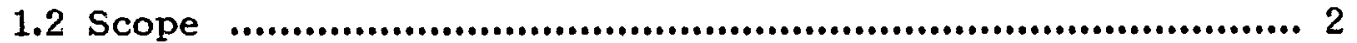

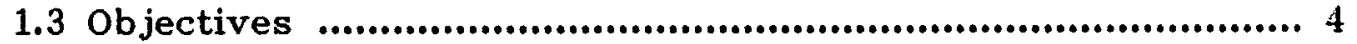

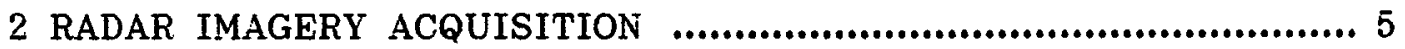

3 NORTH AND SOUTH NEGROS GEOTHERMAL SITES $\ldots \ldots \ldots \ldots \ldots \ldots \ldots \ldots \ldots \ldots . . \ldots 11$

3.1 North Negros Prospect ......................nor.

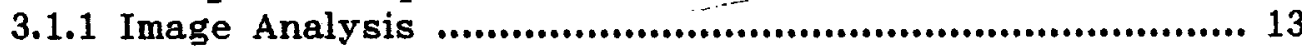

3.2 South Negros Prospect ................................................... 22

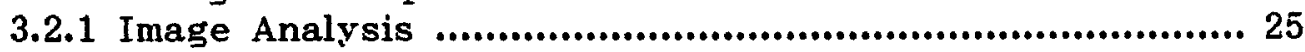

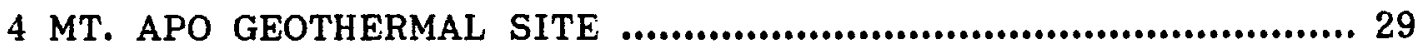

4.1 Summary of Available Geological Information ....................... 29

4.2 Image Analysis ............................................................ 31

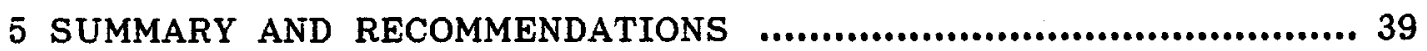

5.1 Radar's Value .................................................................. 40

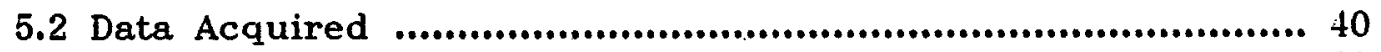

5.3 Data Produced ................................................................... 41

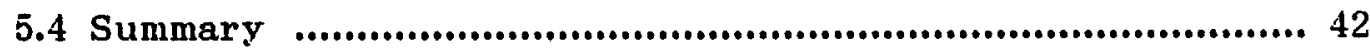

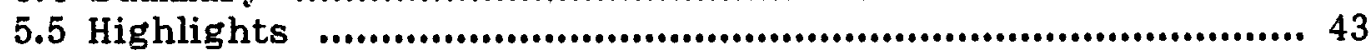

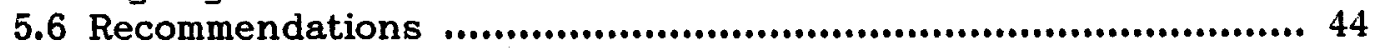

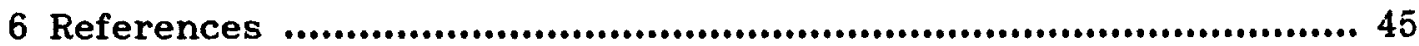




\section{Table of Figures}

1.1: Philippine geothermal areas. ........................................... 3

2.1: Cotabato Basin. ...................................................................... 8

2.2: Cebu and Negros sites. ...................................................... 9

3.1: Location map. ..................................................................... 14

3.2: Map of Negros Island. ................................................... 15

3.3: Geologic map of northern Negros prospect. ......................... 16

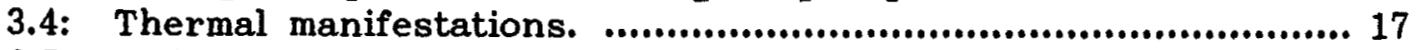

3.5: Radar imagery of Northern Negros. ....................................... 18

3.6: Radar coverage of Northern Negros. .......................................... 19

3.7: Fault interpretation of Northern Negros. .............................. 20

3.8: South Negros geothermal field. ........................................... 23

3.9: Fault systems South Negros. ......................................... 24

3.10: Generalized geologic map of South Negros. ........................... 26

3.11: Radar coverage of South Negros. ......................................... 27

3.12: Fault interpretation of South Negros. ................................... 28

4.1: Mt. Apo Geothermal Prospect. ............................................... 30

4.2: Generalized geologic map of the Mt. Apo area. .................... 32

4.3: Radar coverage of the Mt. Apo Geothermal Prospect. .............. 33

4.4: Fault interpretation of the Mt. Apo area. ............................ 34

4.5: Radar imagery strip of the Mt. Apo area. ........................... 37 


\section{Table of Tables}

2.1: Site coordinates for Philippine radar survey project. .......... 6

2.2: Coverage for Philippines radar survey project. ..................... 10 


\section{INTRODUCTION}

In support of the hydrocarbon exploration program, radar imagery was acquired of four sites in the Philippines (ARCI TR 8701-101, Section 3.3). These sites were selected in coordination with Philippine Bureau of Energy Development (BED) and Philippine National Oil Company Exploration Corporation (PNOC EC) personnel. Site selection was determined from evaluation of the extensive data base of hydrocarbon potential in the Philippines previously assembled by BED and PNOC EC. Selection criteria were not only hydrocarbon potential but regions wherein it was felt the unique perspective of surface structure and features afforded by radar would best complement existing surface and subsurface data. Site selection was limited to a total area of approximately $45,000 \mathrm{~km}^{2}$. Contract negotiations were then initiated with the firm selected to acquire the imagery, Intera Technologies, Inc. Subsequent to these initial negotiations a request was received from the Philippine representatives that coverage of a few small geothermal sites be included in the program even at the expense of dropping one of the hydrocarbon sites selected. During further contract negotiations Intera agreed to cover three small geothermal sites for the fixed maximum price even though this coverage increased the total area to well beyond $45,000 \mathrm{~km}^{2}$. It was stipulated these data were also to have complete stereo coverage, however, no mosaics were to be delivered for the geothermal sites. This essentially no-cost addition of coverage was possible at this stage by selecting geothermal sites that could be imaged during the same flights that hydrocarbon site imagery was collected and in some cases by even sharing the same flight lines. 


\subsection{Background}

Extensive geothermal exploration studies have been conducted in the Philippines over the past decade. More than 40 prospective geothermal resource areas have been identified (Figure 1.1). Thirty-one of these areas have been reconnoitered, 16 explored, 11 test drilled, and 4 have been developed with $894 \mathrm{MW}(\mathrm{e})$ total of generating plants now installed and commissioned (Barnett et al., 1984). Geothermal energy constitutes approximately $20 \%$ of the country's currently installed power generating capacity.

As a result of the numerous comprehensive geothermal investigations conducted by Philippine geoscientists, a systematic procedure has evolved for the exploration and assessment of Philippine geothermal resources. According to Barnett et al. (1984), this procedure consists of the following stages of sequentially higher level investigation:

* Regional identification of prospective target areas

* Geoscientific surface prospecting methods

* Exploration and delineation well drilling

* Assessment of resource potential.

\subsection{ScOpe}

Geothermal areas are normally recognized using the multi-disciplinary integration of data from geological, geochemical, and geophysical investigations. The principal contributions to geothermal exploration provided by geological interpretation of radar imagery might include the recognition of: 


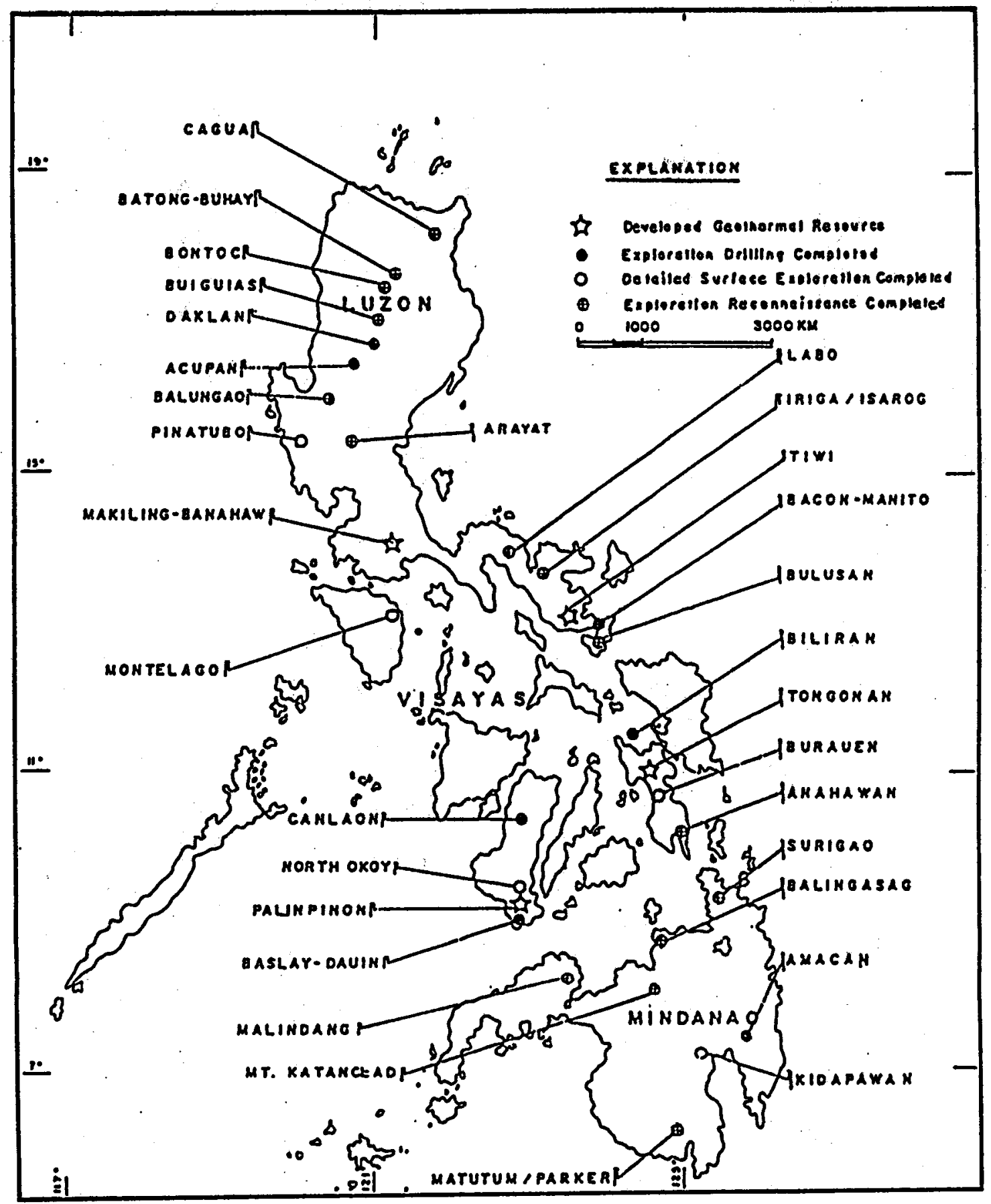

Figure 1.1: Philippine geothermal areas. Areas undergoing exploration and development. (After Barnett et al., 1984). 
* Heat Sources: Potential heat sources can be clearly expressed on the radar imagery as recent volcanic piles or more subtly, as circular features suggesting the potential presence of an old caldera feature or incipient igneous intrusion.

* Plumbing Systems: An adequate plumbing system for convective circulation of geothermal energy is very important. Recognition of linear or curvilinear features which might indicate faulting or fracturing could provide potential hydrothermal conduits and reservoir controls.

* Reservoir Rocks: Normal faults and associated graben systems provide a mechanism for down-dropping high permeability and porous sediments. These sediments produce potentially excellent reservoirs for the collection and storage of geothermal waters.

Detailed surface exploration has been completed in the three areas selected for radar coverage. However, the synoptic radar imagery coverage provides geologic information beyond the areas where extensive geologic mapping has been completed, and provides the capability of integrating regional structural/tectonic features with known geologic data.

\subsection{Objectives}

Faults and fractures that transect a geothermal reservoir are believed to be major contributors to a geothermal's production capability. They may be regarded as channelways or the main trunklines of a geothermal plumbing system. For this reason, a clearer picture of the regional fault/fracture patterns provided by radar interpretation could prove useful in determining permeability controls on fluid upflow, outflow, and surface discharge. Therefore, the objectives of this radar interpretation investigation are to:

* Map the regional fault/fracture patterns

* Determine the significance of the regional fault/fracture pattern when compared with the detailed geologic maps available. 


\section{RADAR IMAGERY ACQUISITION}

The final contract with Intera called for full stereo coverage $(55 \%$ minimum side-lap) of four hydrocarbon and three geothermal sites at a cost based on $45,000 \mathrm{~km}^{2}$, even though actual coverage exceeded this amount. The coordinates of the selected sites, both hydrocarbon and geothermal, are listed in Table 2.1. Sketch maps of the geothermal sites (which also include two hydrocarbon sites) are shown in Figures 2.1 and 2.2.

It should be pointed out that the total coverage actually obtained is well beyond simply the total of both the hydrocarbon and geothermal sites. This is due to extent of the flight lines beyond the boundaries of the contracted areas and extra coverage required to provide full stereo side-lap. While much of this additional coverage is monoscopic, it still represents a significant and valuable addition to the total data acquired. Table 2.2 shows the approximate area of each site along with the additional coverage obtained. Note again that the contracted areas represent complete stereo coverage while much of the additional coverage is monoscopic. 
Table 2.1: Site coordinates for Philippine radar survey project. Hydrocarbon Site 1 - Bondoc Peninsula

\begin{tabular}{|c|c|c|c|}
\hline Point & Coordinates & Point & Coordinates \\
\hline 1 & $13^{\circ} 55^{\prime}$ N $121^{\prime} 41^{\prime} \mathrm{E}$ & 4 & $13^{\prime} 13^{\prime} \mathrm{N} 122^{\prime} 48^{\prime} \mathrm{E}$ \\
\hline 2 & $13^{\prime} 31^{\prime} \mathrm{N} 122^{\prime} 18^{\prime} \mathrm{E}$ & 5 & $13^{\prime} 52^{\prime} \mathrm{N} 122^{\prime} 31^{\prime} \mathrm{E}$ \\
\hline 3 & $13^{\circ} 08^{\prime} \mathrm{N} 122^{\prime} 35^{\prime} \mathrm{E}$ & 6 & $14^{\circ} 17^{\prime} \mathrm{N} 121^{\prime} 57^{\prime} \mathrm{E}$ \\
\hline
\end{tabular}

Hydrocarbon Site 2 - Cotabato Basin, Mindanao

\begin{tabular}{|c|c|c|c|}
\hline Point & Coordinates & Point & Coordinates \\
\hline 1 & $7^{\circ} 07^{\prime} \mathrm{N} 123^{\circ} 55^{\prime} \mathrm{E}$ & 3 & $6^{\circ} 22^{\prime} \mathrm{N} 125^{\prime} 42^{\prime} \mathrm{E}$ \\
\hline 2 & $5^{\circ} 50^{\prime} \mathrm{N} 125^{\circ} 00^{\prime} \mathrm{E}$ & 4 & $7^{\circ} 30^{\prime} \mathrm{N} 124^{\circ} 40^{\prime} \mathrm{E}$ \\
\hline
\end{tabular}

Hydrocarbon Site 3 - Mindoro

\begin{tabular}{|c|c|c|c|}
\hline Point & Coordinates & Point & Coordinates \\
\hline 1 & $13^{\prime} 15^{\prime} \mathrm{N} 120^{\prime} 32^{\prime} \mathrm{E}$ & 4 & $12^{\prime} 41^{\prime} \mathrm{N} 121^{\prime} 35^{\prime} \mathrm{E}$ \\
\hline 2 & $12^{\prime} 11^{\prime} \mathrm{N} 121^{\prime} 00^{\prime} \mathrm{E}$ & 5 & $13^{\prime} 02^{\prime} \mathrm{N} 121^{\prime} 30^{\prime} \mathrm{E}$ \\
\hline 3 & $12^{\prime} 11^{\prime} \mathrm{N} 121^{\prime} 26^{\prime} \mathrm{E}$ & & \\
\hline
\end{tabular}


Hydrocarbon Site 4 - Cebu

\begin{tabular}{|c|c|c|c|}
\hline Point & Coordinates & Point & Coordinates \\
\hline 1 & $11^{\prime} 17^{\prime} \mathrm{N} 123^{\prime} 58^{\prime} \mathrm{E}$ & 5 & $9 \cdot 23^{\prime} \mathrm{N} 123^{\prime} 24^{\prime} \mathrm{E}$ \\
\hline 2 & $10^{\circ} 30^{\prime} \mathrm{N} 123^{\prime} 41^{\prime} \mathrm{E}$ & 6 & $10^{\circ} 00^{\prime} \mathrm{N} 123^{\prime} 41^{\prime} \mathrm{E}$ \\
\hline 3 & $10^{\circ} 00^{\prime} \mathrm{N} 123^{\prime} 21^{\prime} \mathrm{E}$ & 7 & $10^{\circ} 26^{\prime} \mathrm{N} 124^{\prime} \mathrm{O} 4^{\prime} \mathrm{E}$ \\
\hline 4 & $9^{\prime} 23^{\prime} \mathrm{N} 123^{\prime} 16^{\prime} \mathrm{E}$ & 8 & $11^{\prime} 17^{\prime} \mathrm{N} 124^{\prime} \mathrm{O} 6^{\prime} \mathrm{E}$ \\
\hline
\end{tabular}

Geothermal Site A - North Negros

\begin{tabular}{|c|c|c|c|}
\hline Point & Coordinates & Point & Coordinates \\
\hline 1 & $10^{\circ} 41^{\prime} \mathrm{N} 123^{\circ} 00^{\prime} \mathrm{E}$ & 3 & $10^{\prime} 18^{\prime} \mathrm{N} 123^{\prime} 20^{\prime} \mathrm{E}$ \\
\hline 2 & $10^{\prime} 18^{\prime} \mathrm{N} 123^{\circ} 00^{\prime} \mathrm{E}$ & 4 & $10^{\prime} 41^{\prime} \mathrm{N} 123^{\prime} 20^{\prime} \mathrm{E}$ \\
\hline
\end{tabular}

Geothermal Site B - South Negros

\begin{tabular}{|c|c|c|c|}
\hline Point & Coordinates & Point & Coordinates \\
\hline 1 & $90^{\circ} 30^{\prime} \mathrm{N} 123^{\circ} 00^{\prime} \mathrm{E}$ & 4 & $9^{\circ} 19^{\prime} \mathrm{N} \quad 123^{\circ} 19^{\prime} \mathrm{E}$ \\
\hline 2 & $90^{\circ} 03^{\prime} \mathrm{N} 123^{\circ} 00^{\prime} \mathrm{E}$ & 5 & $9 \cdot 30^{\prime} \mathrm{N} \quad 123^{\circ} 11^{\prime} \mathrm{E}$ \\
\hline 3 & $g^{\circ} 03^{\prime} \mathrm{N} 123^{\circ} 09^{\prime} \mathrm{E}$ & & \\
\hline
\end{tabular}

Geothermal Site C - Mt. Apo, Mindanao

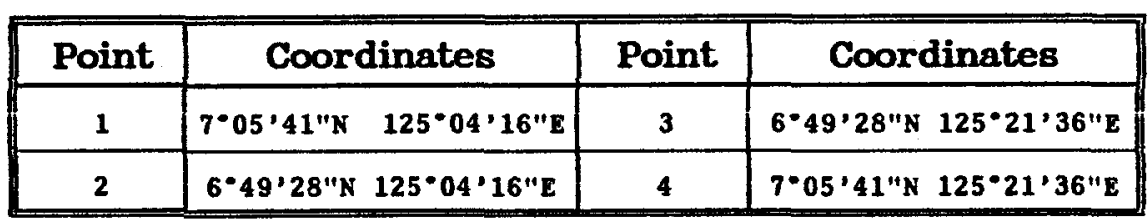




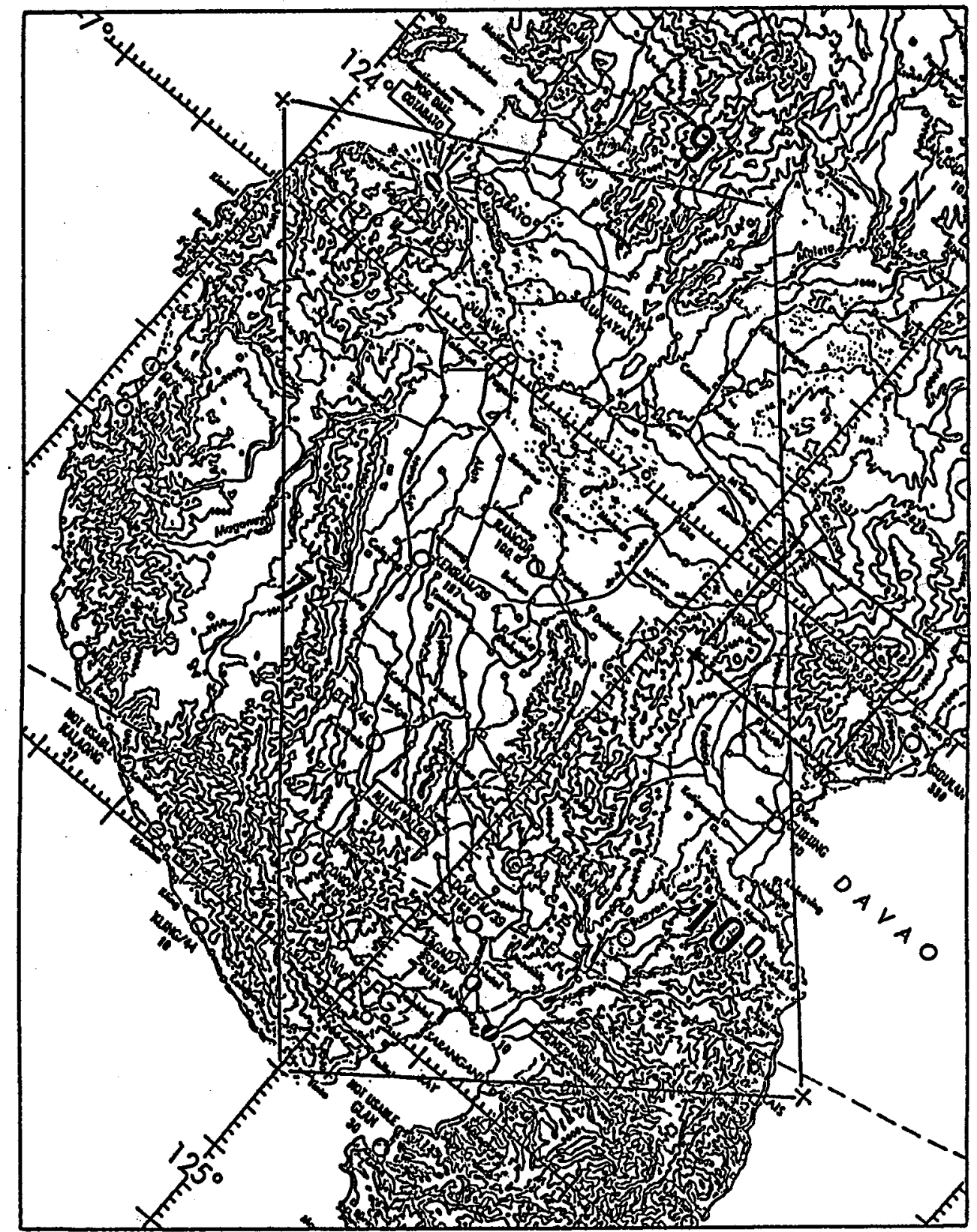

Figure 2.1: Cotabato Basin. Mindanao hydrocarbon site and Mt. Apo geothermal site. 


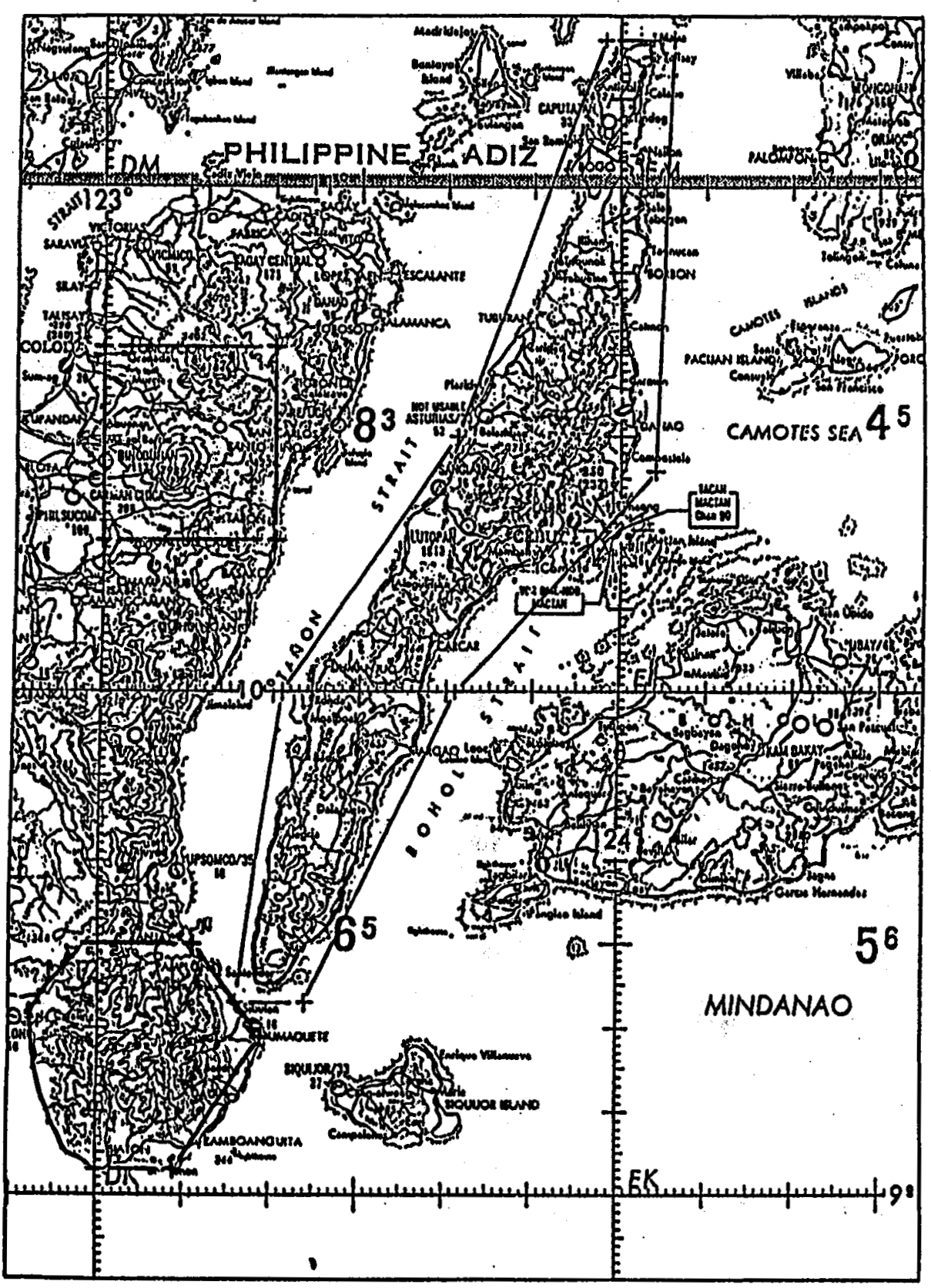

Figure 2.2: Cebu and Negros sites. Cebu hydrocarbon site, and North and South Negros geothermal sites. 
Table 2.2: Coverage for Philippines radar survey project. MTDROCAREON SITES

\begin{tabular}{|l|c|c|c|}
\hline Site & $\begin{array}{c}\text { Contract } \\
\left(\mathrm{km}^{2}\right)\end{array}$ & $\begin{array}{c}\text { Area } \\
\text { Additional } \\
\left(\mathrm{km}^{2}\right)\end{array}$ & Total (km²) \\
\hline Bondoc Peninsula & 6,250 & 2,010 & 8,260 \\
\hline Cotabato Basin, Mindanao & 19,000 & 3,265 & 22,265 \\
\hline Mindoro & 11,500 & 2,100 & 13,600 \\
\hline Cebu & 7,525 & 400 & 7,925 \\
\hline & 14,275 & 7,775 & 52,050 \\
\hline
\end{tabular}

\section{GEOTFERMAT. STTES}

\begin{tabular}{|r|c|c|c|}
\hline North Negros & 1,325 & 2,600 & 3,925 \\
\hline South Negros & 1,570 & 930 & 2,500 \\
\hline Mt. Apo & 715 & 1,735 & 2,450 \\
\hline Subtotal & 3,610 & 5,265 & 8,875 \\
\hline GRArD TOTAL & 17,885 & 13,040 & 60,925 \\
\hline
\end{tabular}




\section{NORTH AND SOUTH NEGROS GEO- THERMAL SITES}

The background geologic information in this section has been summarized from reports provided by the Philippine National Oil Company Energy Development Corporation (PNOC-EDC) including; Alcaraz (1984), Alincastre (1983), Harper and Arevalo (1983), and Seatres (1982). Four geologic-related maps (scale 1:50,000) were also provided:

* North Negros - Structural/Geologic Map, Northern Geothermal Prospect, Mambucal Negros Occidental, PNOC-EDC, 1984

* Southern Negros - Geologic Map of North Okoy and Structural Alteration Map of Palinpinon and Baslay-Dauin, PNOC-EDC, 1984

* Lithologic Map - Southern Negros Geothermal Project, PNOCEDC, 1984

* Fracture System(s) Map - Southern Negros Geothermal Project, PNOC-EDC, 1984.

Negros Island is situated in the western region of the Visayan group of islands and is bounded on the east by Tanon Strait, Guimaras Strait on the west, Visayan Sea on the north and Sulu Sea on the south (Figure 3.1). Generally, Negros Island is underlain by undifferentiated pre-Tertiary rocks consisting mainly of graywackes and meta-volcanics which are believed to be the basement rock (Alincastre, 1983). Extensive exposures of these rocks can be found on the southwestern part of the island. These pre-Tertiary rocks are overlain by a thick sequence of Tertiary to Quaternary sedimentary rocks intercalated by volcanics of andesitic, basaltic and dacitic composition. The sedimentary formations are composed of limestone and sedimentary clastics which comprise the eastern cordillera. Neogene intrusives, generally quartz diorite occur on the southwestern 
part of the island. These intrusives are probably responsible for the emplacement of copper porphyry deposits which are presently mined in the area. Alincastre (1983) provided a generalized geology map of Negros Island; reproduced as Figure 3.2 .

The Island is further characterized by several dormant, and an active, volcanic centers; Mount Mandalagan, Mount Silay and Canlaon Volcano (active) on the north and the coalescing volcanos of Cuernos de Negros, Guinsayawan, and Guintabon in the south (Figure 3.2).

\subsection{North Negros Prospect}

The prospect area (approximately $1100 \mathrm{~km}^{2}$ ) is characterized by moderately sloping topography which rises abruptly in the vicinity of Mt. Canlaon $(2455 \mathrm{~m})$, an active volcano. Towards the north-northeast the topography is dominated by two extinct, deeply dissected volcanic centers; Mt. Mandalagan and Mt. Silay (Figure 3.2). Geologic structures in the area such as volcanos and volcanic lineaments, collapse features, fractures and joints, and faults were mapped by Alincastre (1983) and are illustrated in Figure 3.3.

In 1982, a detailed geologic survey was conducted in a $278 \mathrm{~km}^{2}$ area of the Northern Negros Geothermal Prospect (Alincastre, 1983). The investigation focused on three previously defined, low resistivity anomalies in the Saray, Mambucal, and Hagdan areas (Figure 3.3). Thermal features (manifestations) such as hot/warm springs, altered ground, and gas seepages were mapped (Figure 3.4). Alincastre (1983) concluded that the presence of the Saray volcanic plug, north of Mt. Canlaon suggests that a heat source at Mambucal, Saray and Hagdan areas is closely related to the Saray plug rather than the active Canlaon crater. He also reported that no fault 
of major extent was encountered in the area. However, the thermal manifestations in the Mambucal, Saray, and Hagdan areas are probably related to radial fractures or old structures buried by recent volcanism.

\subsubsection{Image Analysis}

The Northern Negros Geothermal Prospect, as outlined on the generalized geologic map (Figure 3.3), has been positioned on part of a radar imagery strip (Figure 3.5). For viewing purposes, and to avoid topographic inversion, the radar imagery has been rotated counter clockwise 90 degrees. Figure 3.6 shows the radar coverage of the Northern Negros Geothermal Prospect area (Figure 3.1), and has been used for illustration purposes even though considerable radar shadowing occurs in the Mt. Canlaon area.

Monoscopic and stereoscopic analysis of the imagery has allowed highlighting of numerous faults and fault patterns (Figure 3.7). In the vicinity of Mt. Canlaon and Mt. Mandalagan the dominant fault patterns are oriented in northeast-southwest and northwest-southeast directions. A highly conspicuous northwest-southeast trending fault separates the Mt. Canlaon and $\mathrm{Mt}$. Mandalagan geothermal areas, and coincides with the channel of the Bago River. A similar fault separates the Mt. Mandalagan and Mt. Silay geothermal areas.

A high concentration of less regionally extensive faulting occurs on the northeastern slope of the Canlaon geothermal area. This intersecting network of closely spaced small scale fractures clearly suggests a zone of structural weakness. The sloping surface in this area appears extremely rough on radar imagery due to the presence of numerous highly dissected fault scarps. The absence of the characteristic volcanic flow features and high drainage density suggests the presence of a well consolidated lithologic unit. 


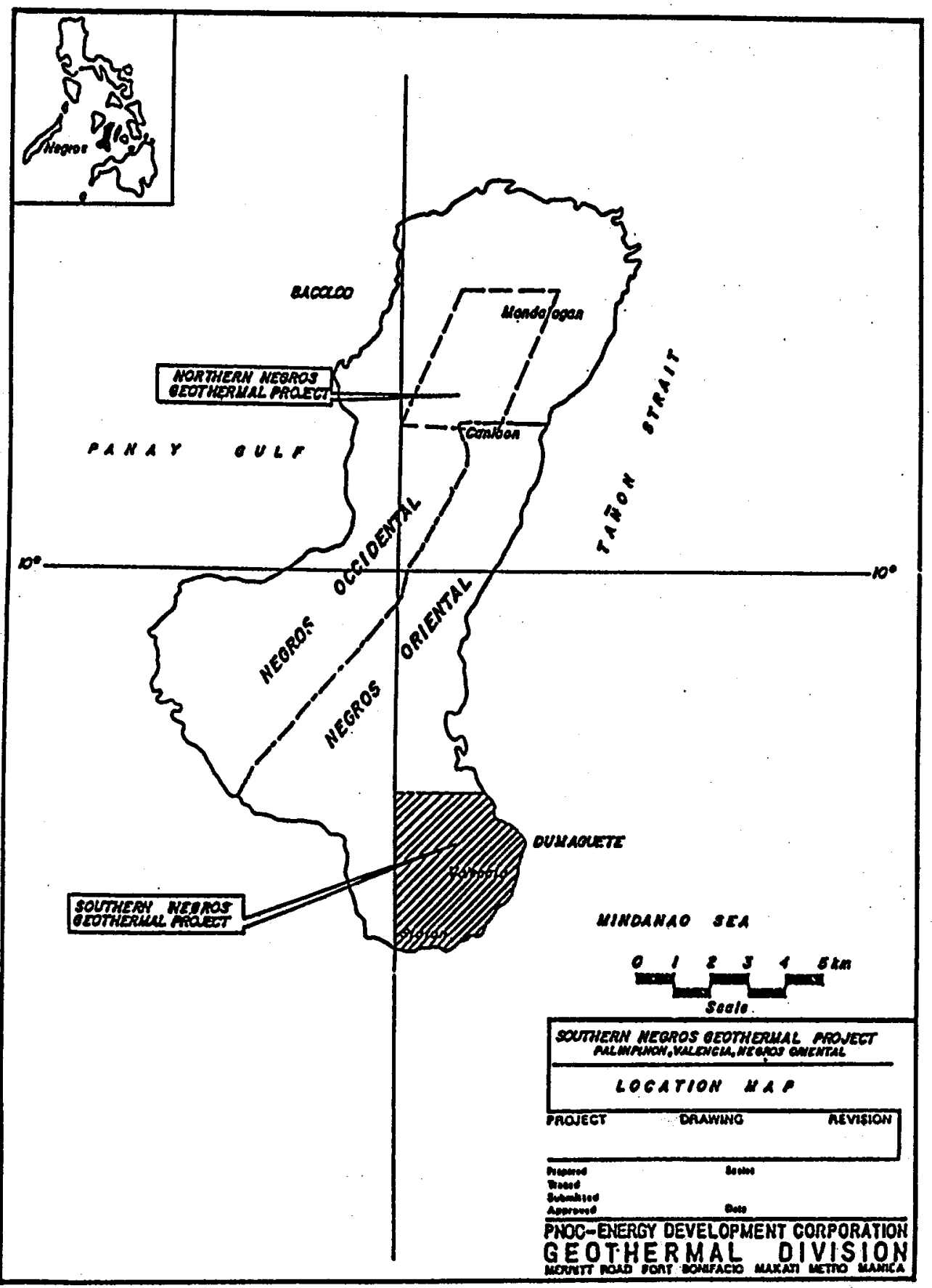

Figure 3.1: Location wap. (After Alincastre, 1983). 


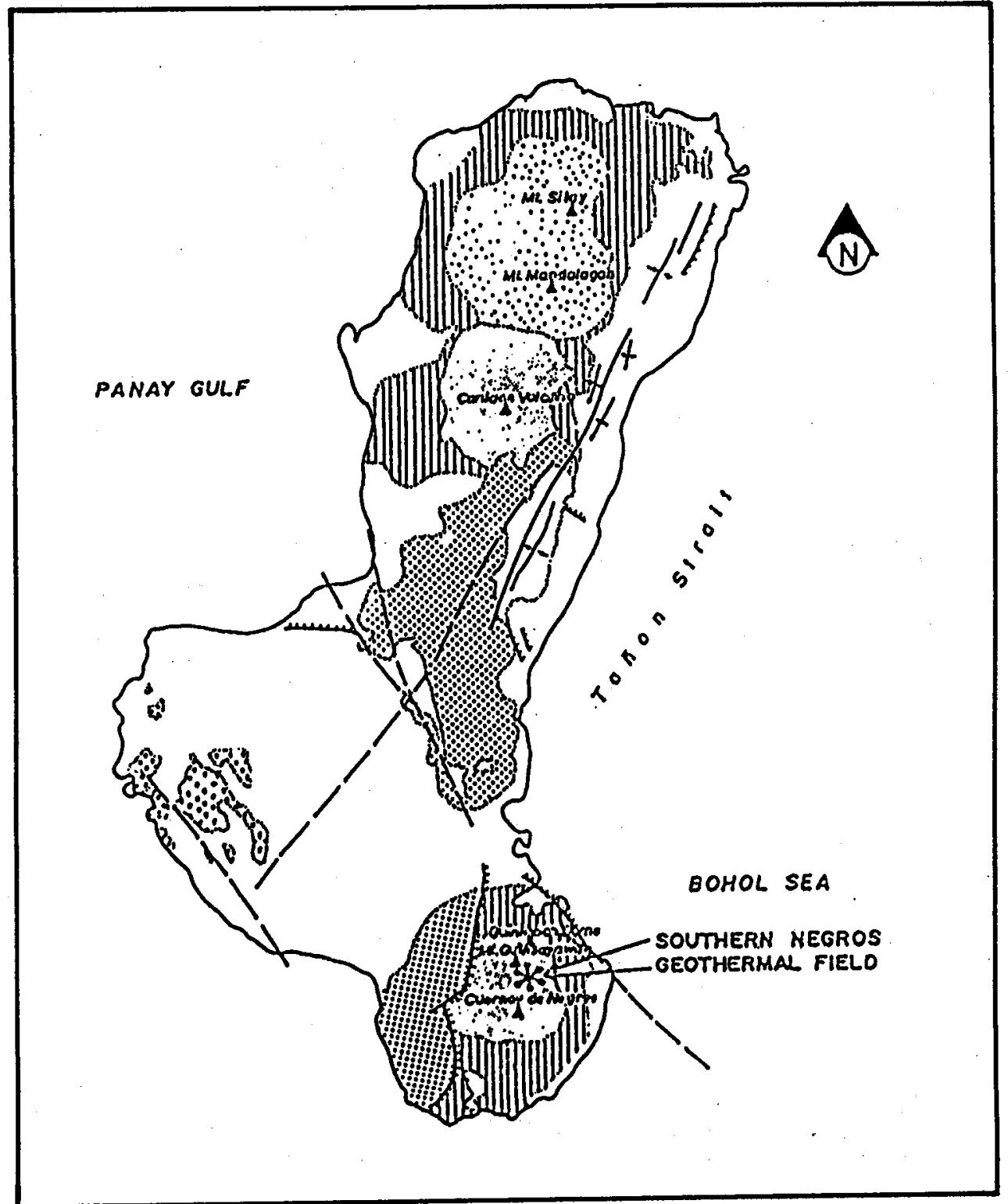

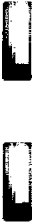

cegenO1 H Geothermat liew

- stactinat oxil with pluspe

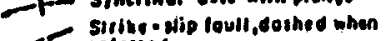

inceries

$\square$ Upper miocene eroeons sodimenls

Dovelerinery ective rolcene

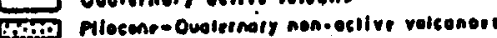

(IIIIIIIII) Miocens Ovolosnery rulcente ploin

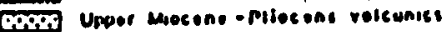

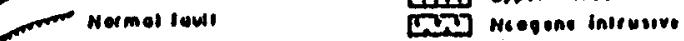

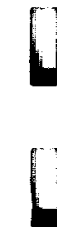

Figure 3.2: Map of Negros Island. Map shows generalized geology and structures. (After Alincastre, 1983). 


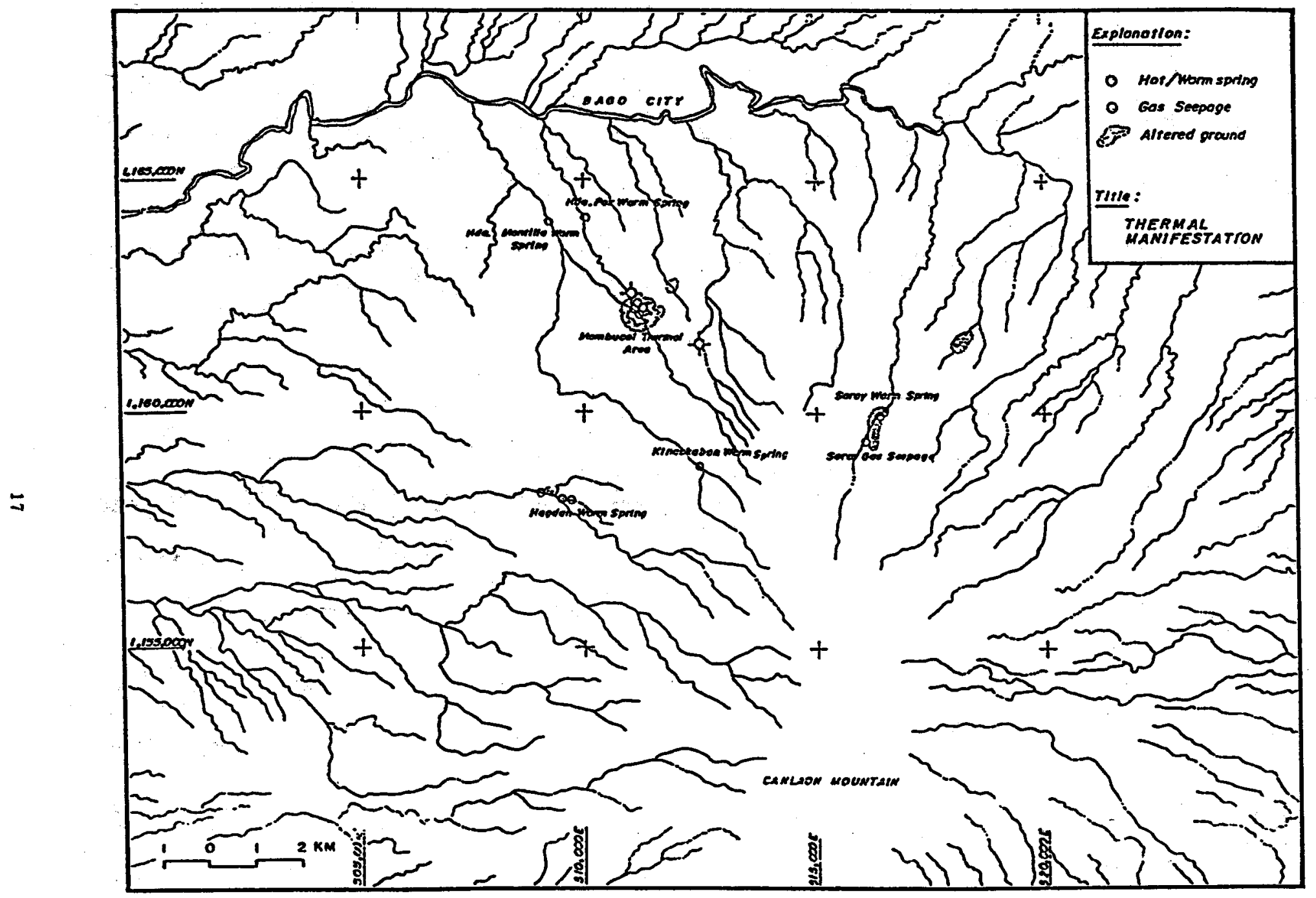

Figure 3.4: Thermal manifestations. (After Alincastre, 1983). 


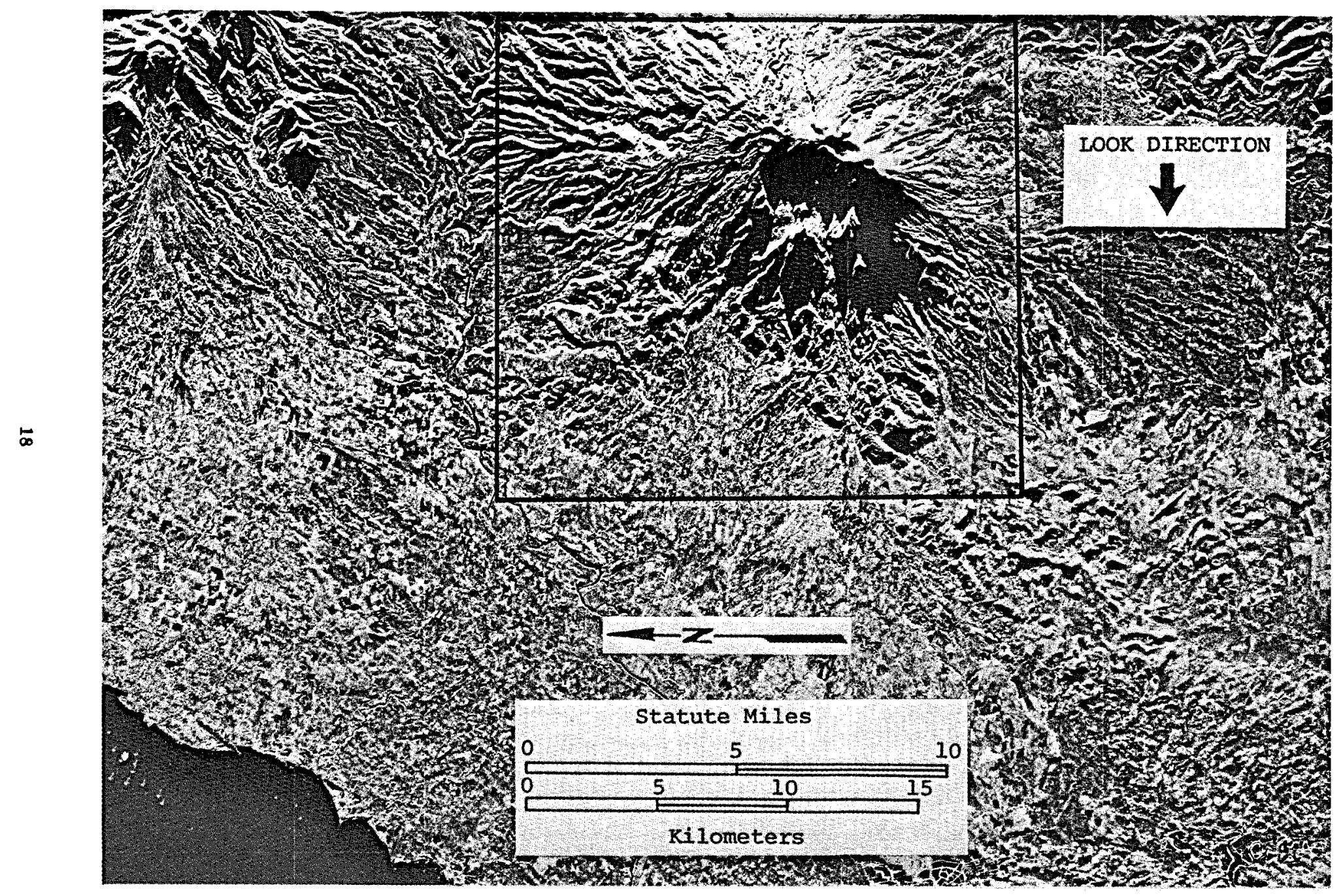

Figure 3.5: Radar imagery of Northern Negros. Radar strip of the Northern

Negros Geothermal Prospect shows the outline of Figure 3.3. 


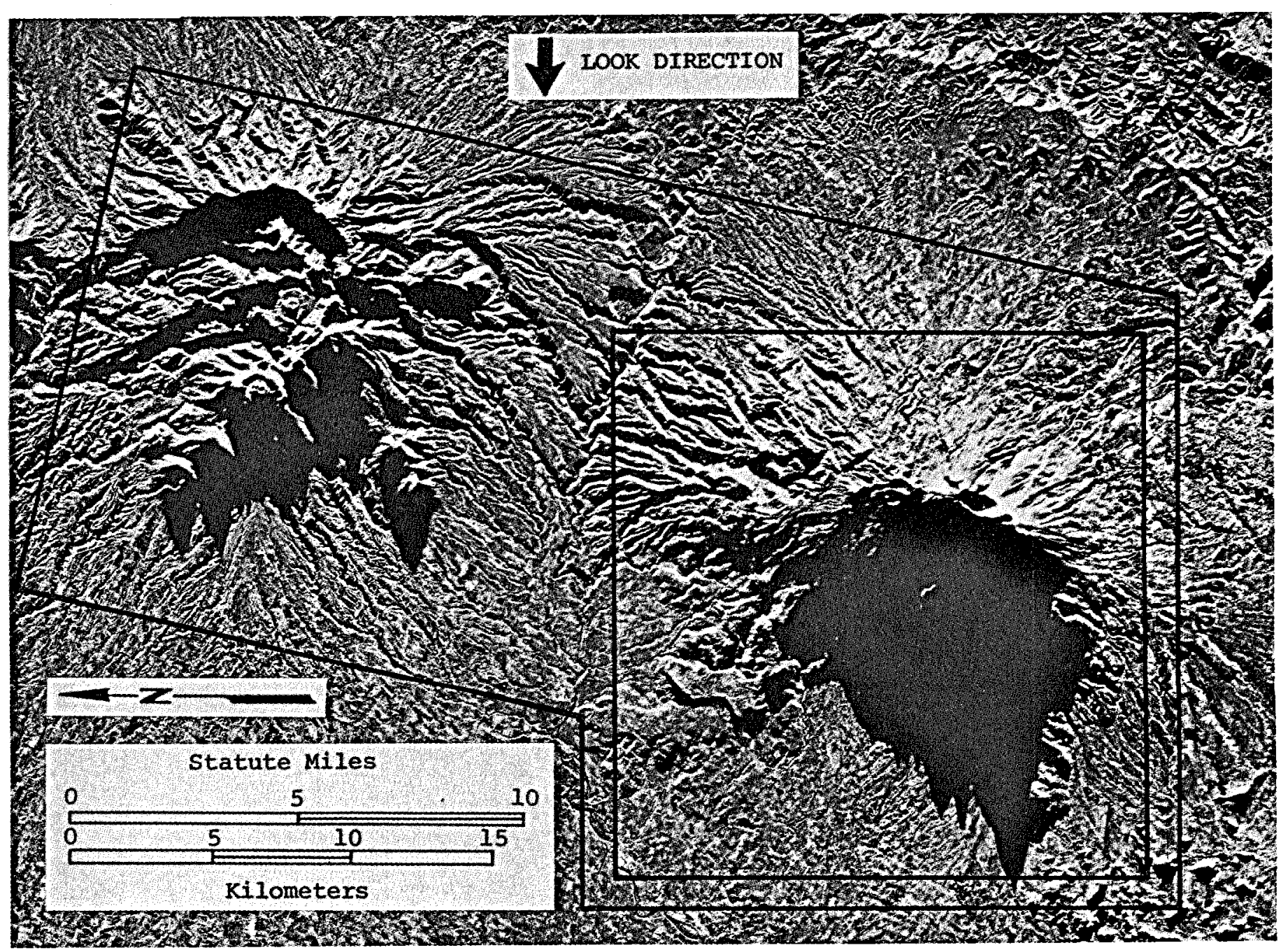

Figure 3.6: Radar coverage of Northern Negros. Geothermal prospect area is shown. 


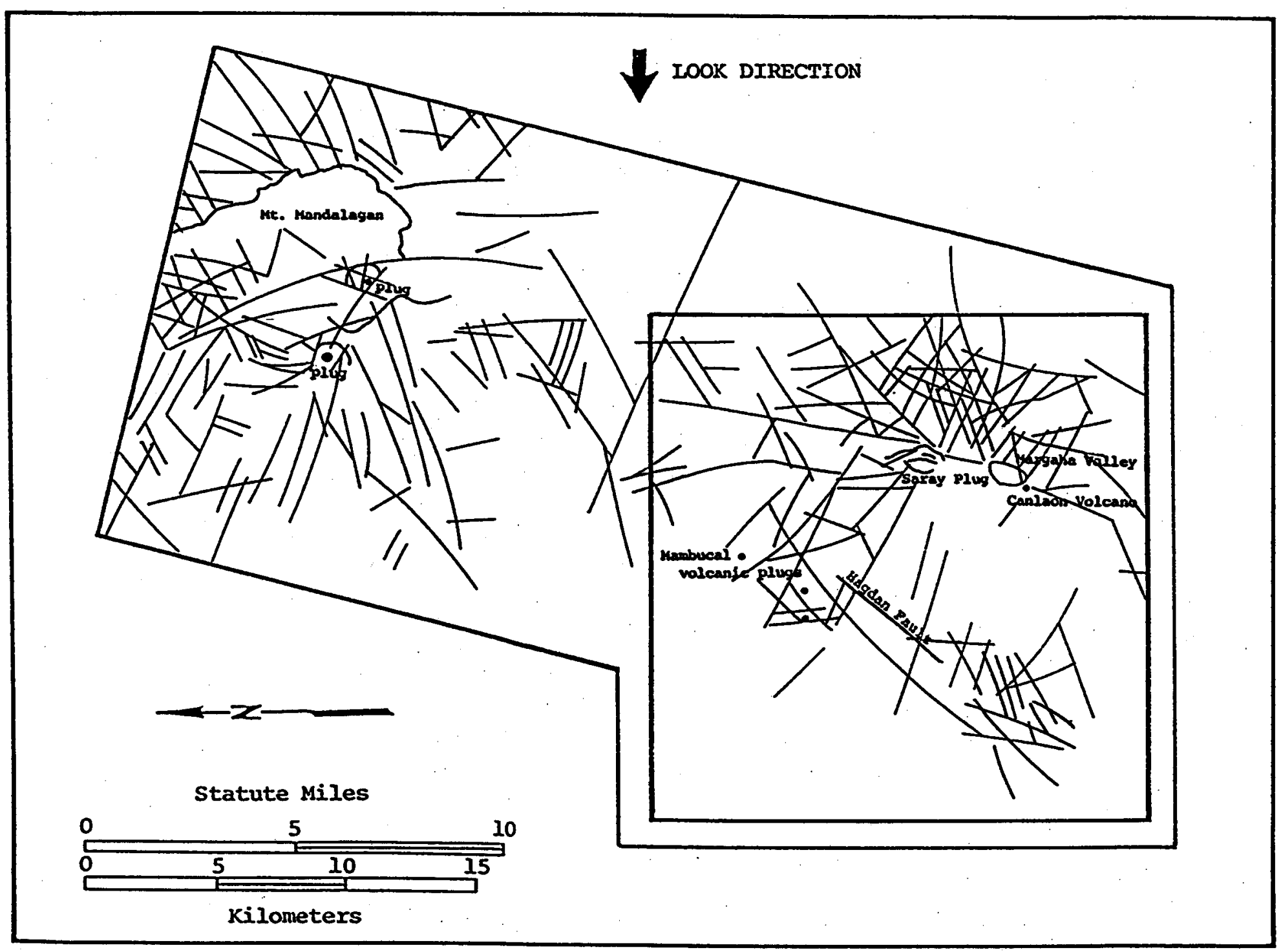

Figure 3.7: Fault interpretation of Northern Negros. Interpretation of the geothermal prospect is shown. 
Volcanic features that can be identified on radar imagery of the Mt. Canlaon region include:

(1) The active Canlaon Volcano

(2) An older inactive crater located due north of the Canlaon Volcano which now forms the Mangaha Valley depression

(3) The Saray Plug and Saray depression

(4) Several small volcanic plugs and an associated field of recent lava flows in the Mambucal area

The Mt. Mandalagan structural style is dominated by a large highly dissected crater. The eastern rim of this feature is defined by a steeply dipping curvilinear escarpment which causes prominent radar shadow in the backslope region. Other volcanic structures identified in this area include:

(1) A small volcanic plug and associated area of recent lava located in the central to western region of the crater

(2) A larger elevated plug and peripheral rim structure located on the western slope of the Mt. Mandalagan geothermal area

As previously mentioned, the Mt. Mandalagan area is highly dissected by faults and drainage channels. Major faults transect crater walls and intersect in the central and west central region of the crater. Less regionally extensive faulting is prevalent throughout the area. The highest concentration of faults occurs a small distance west of the Napilas River in the northern region of the Mt. Mandalagan area.

The use of radar imagery has increased the amount of available geologic information in the Mt. Canlaon and Mt. Mandalagan areas. A number of faults have been inferred in the vicinity of the Saray Plug; however, detailed field work may be necessary to confirm these features. 
Areas of radar shadow, caused by the steeply dipping, high relief volcanic features, can result in loss of interpretive data. This problem was partially resolved by using an image which provided an alternative viewing perspective, created by a change in the flight path of the aircraft (Figure 3.5).

\subsection{South Negros Prospect}

The Southern Negros Geothermal Reservation includes an area of approximately $1300 \mathrm{~km}^{2}$. The South Negros geothermal field (Figure 3.8) encompasses the sectors of Puhagan and Nasuji - Sonongon (Seastres, 1982). Production of geothermal fluids in the Puhagan sector comes from four sources: (1) intraformational permeability, (2) lithologic contacts, (3) fractures induced by intrusive bodies, and (4) faults (Alcaraz, 1984). These fluids are now used to generate $112.5 \mathrm{MW}(e)$ of electrical power from the area.

A structural map of the Southern Negros geothermal field was presented by Alcaraz (1984), and is shown in Figure 3.9. Detailed geologic information for the Southern Negros Geothermal Reservation area, compiled from field surveys, photo interpretation and a synthesis of previous reports is provided on the three PNOC-EDC (1984) maps listed in Section 3. 


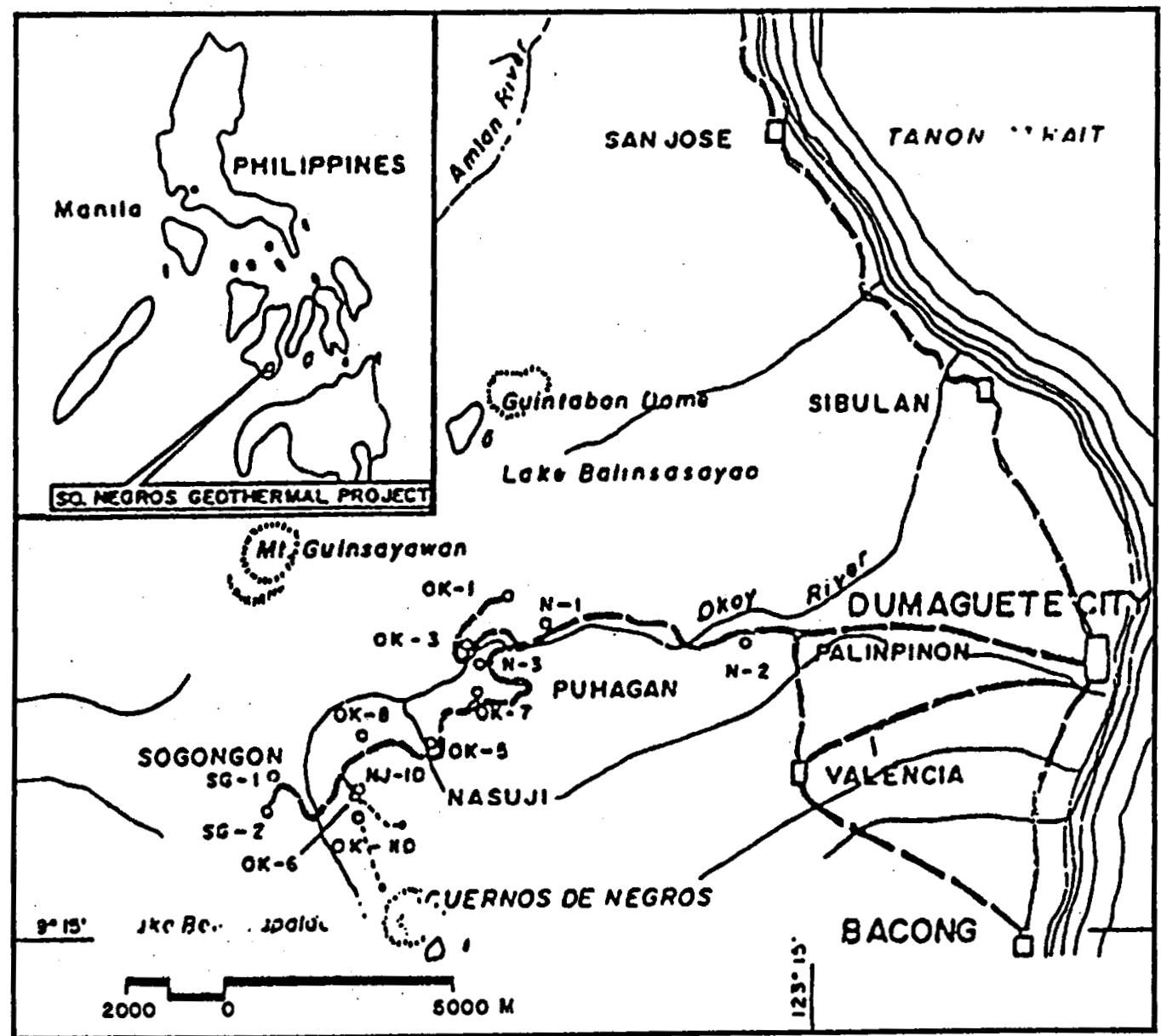

Figure 3.8: South Negros geothermal field. Location of drilled test wells is shown. (After Seastres, 1982). 


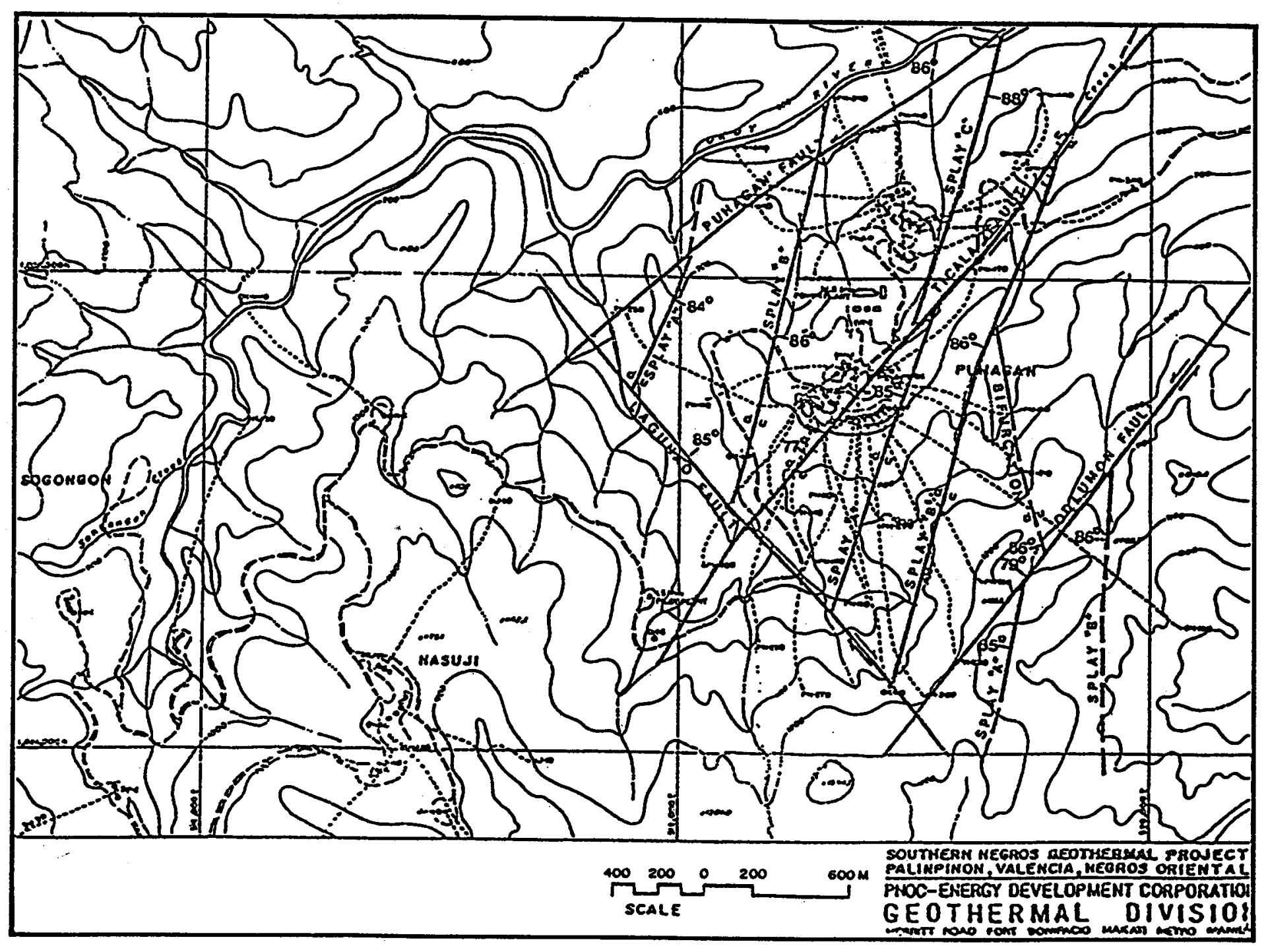

Figure 3.9: Fault systems of South Negros. Puhagan area, South Negros geothermal field, is shown. (After Alcaraz, 1984). 


\subsubsection{Image Analyeis}

The South Negros Geothermal Project area, as outlined on the generalized geologic map (Figure 3.10 ) has been located on a radar imagery strip (Figure 3.11). For viewing purposes, the imagery has been rotated counter clockwise approximately 135 degrees to avoid topographic inversion. Monoscopic and stereoscopic analysis of the imagery has allowed for the inference of many faults and fault patterns (Figure 3.12).

Faults in the South Negros Geothermal Project area appear to have two dominant orientations:

(1) A northwest-southeast trending group that includes the Okoy, Manguto, and Calinawan Faults and several radar-inferred faults

(2) A northeast-southwest trending group that includes the Nagambi, Ticala, Malaunay, and Siaton Faults and additional radar-inferred faults.

Other less dominant faults are oriented in a north-south direction parallel to the trend of the major volcanic features. These faults are in general only locally expressed and occur near collapse features. High concentrations of small scale fractures are located on the eastern slope of Mt. Guinsayawan and in the large depression to the southeast of Cuernos de Negros.

The regional structural style of the South Negros Geothermal Project area appears to be dominated by the northwest-southeast trending fault pattern. This fault pattern can be easily identified on radar imagery in locations outside the project area to the west and northwest. Several of the major faults extend outside the project area boundaries to the east, forming an area of rugged topographic relief. 


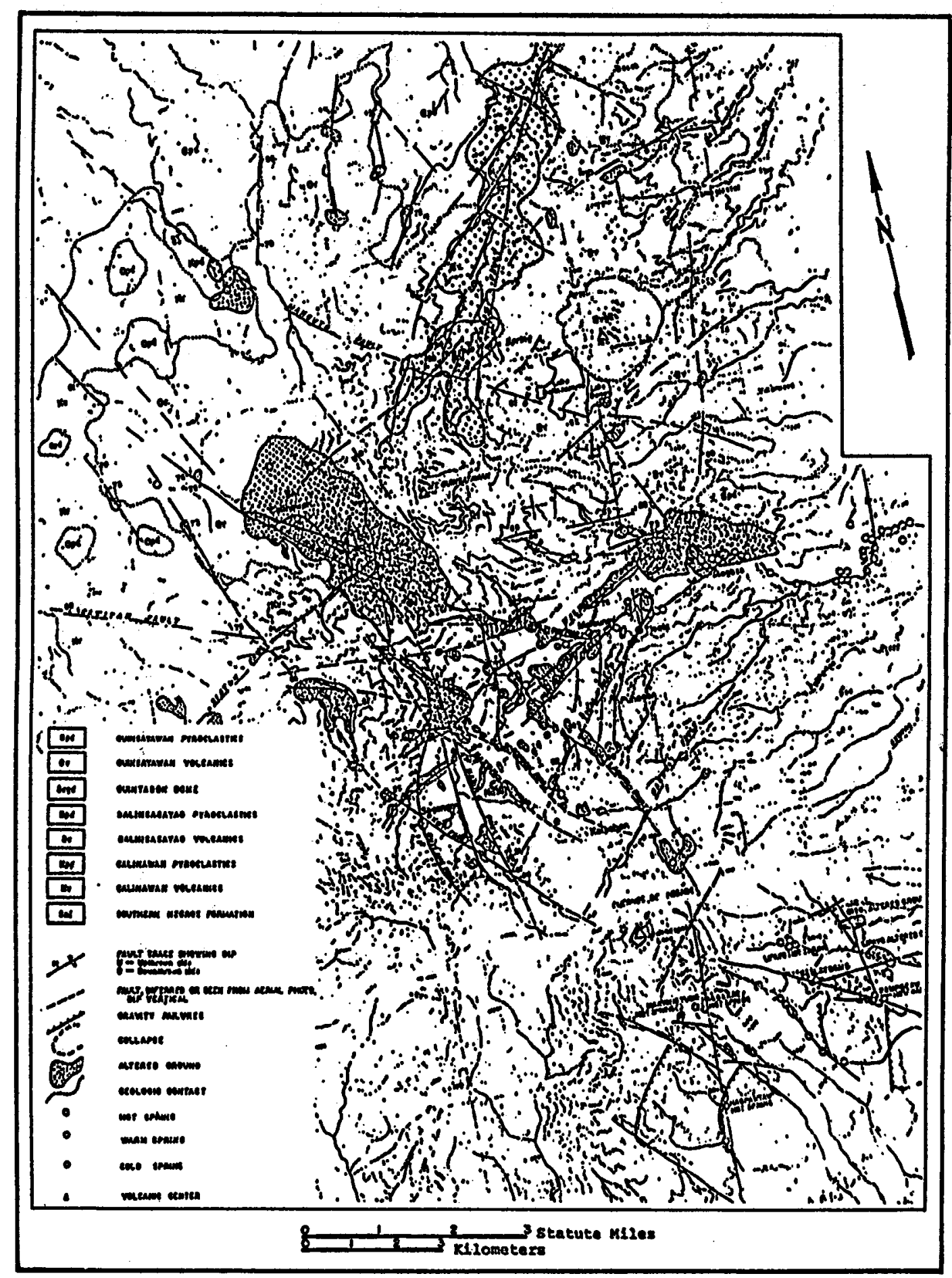

Figure 3.10: Generalized geologic map of South Negros. Geothermal Prospect area is shown. (After PNOC EC, 1984). 


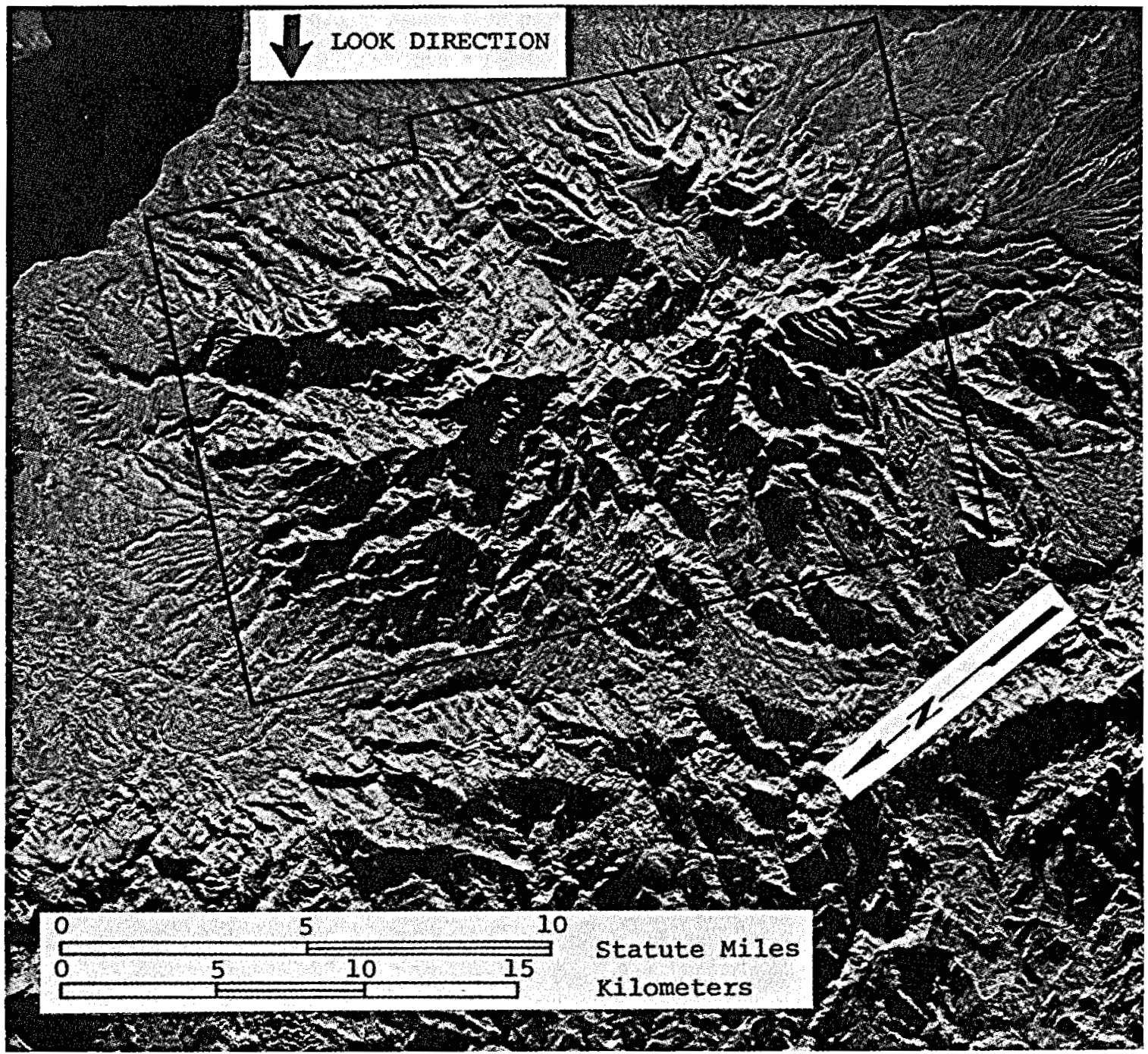

Figure 3.11: Radar coverage of South Negros. Geothermal Prospect area is shown. 


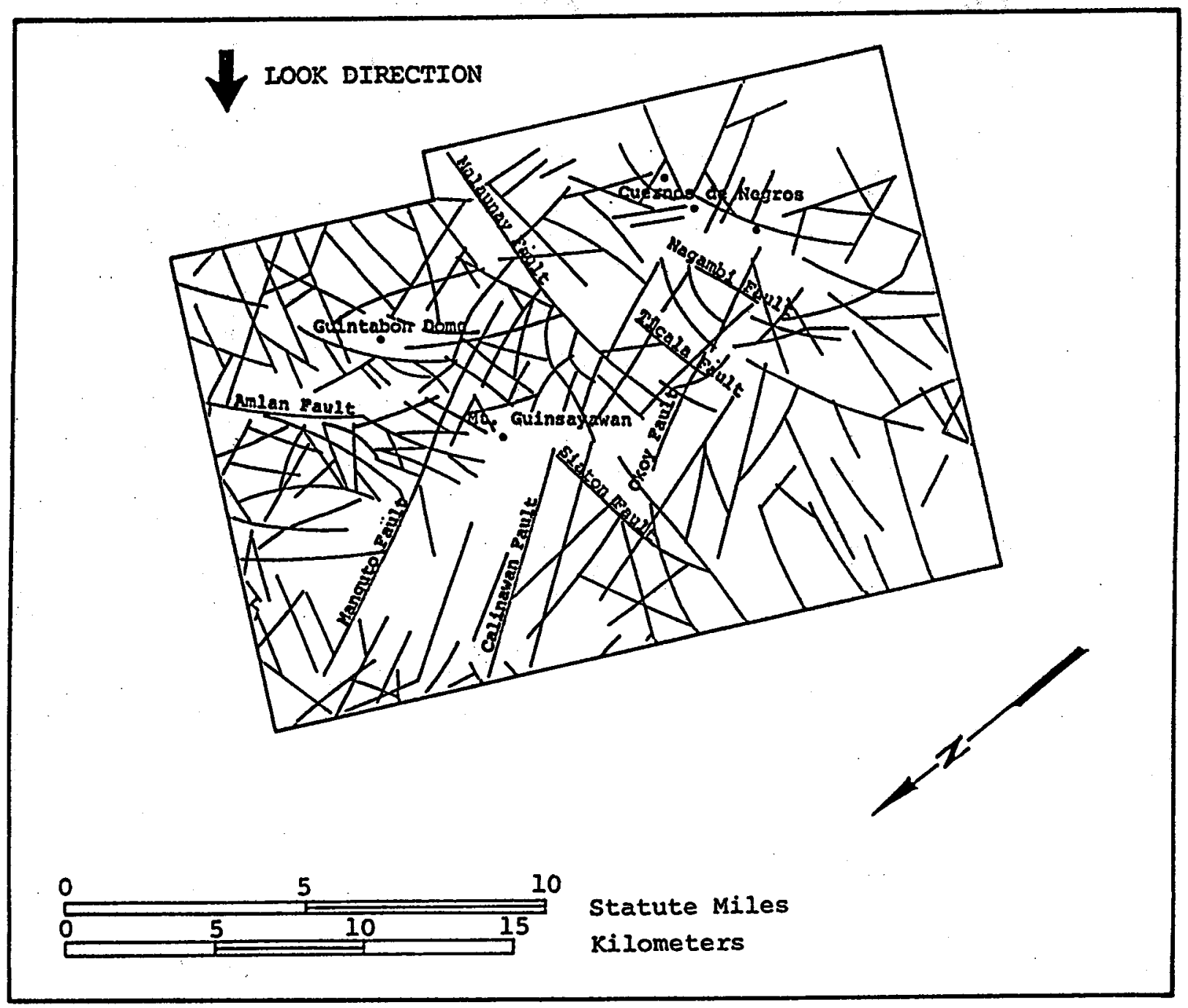

Figure 3.12: Fault interpretation of South Negros. Geothermal Prospect area is shown. 


\section{MT. APO GEOTHERMAL SITE}

The background geologic information in this section has been summarized from a report provided by PNOC-EDC, and compiled by Deflin and Castro (1984). Two geologic-related maps were also provided: (1) Mt. Apo Geothermal Prospect - Kidapawan, North Cotabato Mindanao, PNOC-EDC 1987, Scale 1:50,000, and (2) Mt. Apo Geothermal Prospect - Province of Cotabato and Darao, PNOC-EDC 1984, Scale 1:20,000.

Mt. Apo, located in southcentral Mindanao approximately $40 \mathrm{~km}$ west of Darao City (Figure 4.1), is the Philippines' highest peak with an elevation of $2954 \mathrm{~m}$. Since March 1983, PNOC-EDC has conducted an integrated geoscientific investigation in the area in order to assess Mt. Apo's geothermal potential and locate the most promising areas for deep drilling and development (Deflin and Castro, 1984).

\subsection{Summary of Available Geological Information}

The Mt. Apo volcanic field is part of a north-south trending chain of late Tertiary-Quaternary composite volcanos. This range separates the Agusan - Darao trough on the east from the Cotabato basin to the west. Mt. Apo and two other major composite volcanos (Mt. Sibulan and Mt. Talomo) within the geothermal prospect area have probable Pliocene to Quaternary age volcanics on their flanks. The Sibulan volcanics are believed to be oldest, the Talomo volcanics intermediate, and the Apo volcanics youngest in age. 


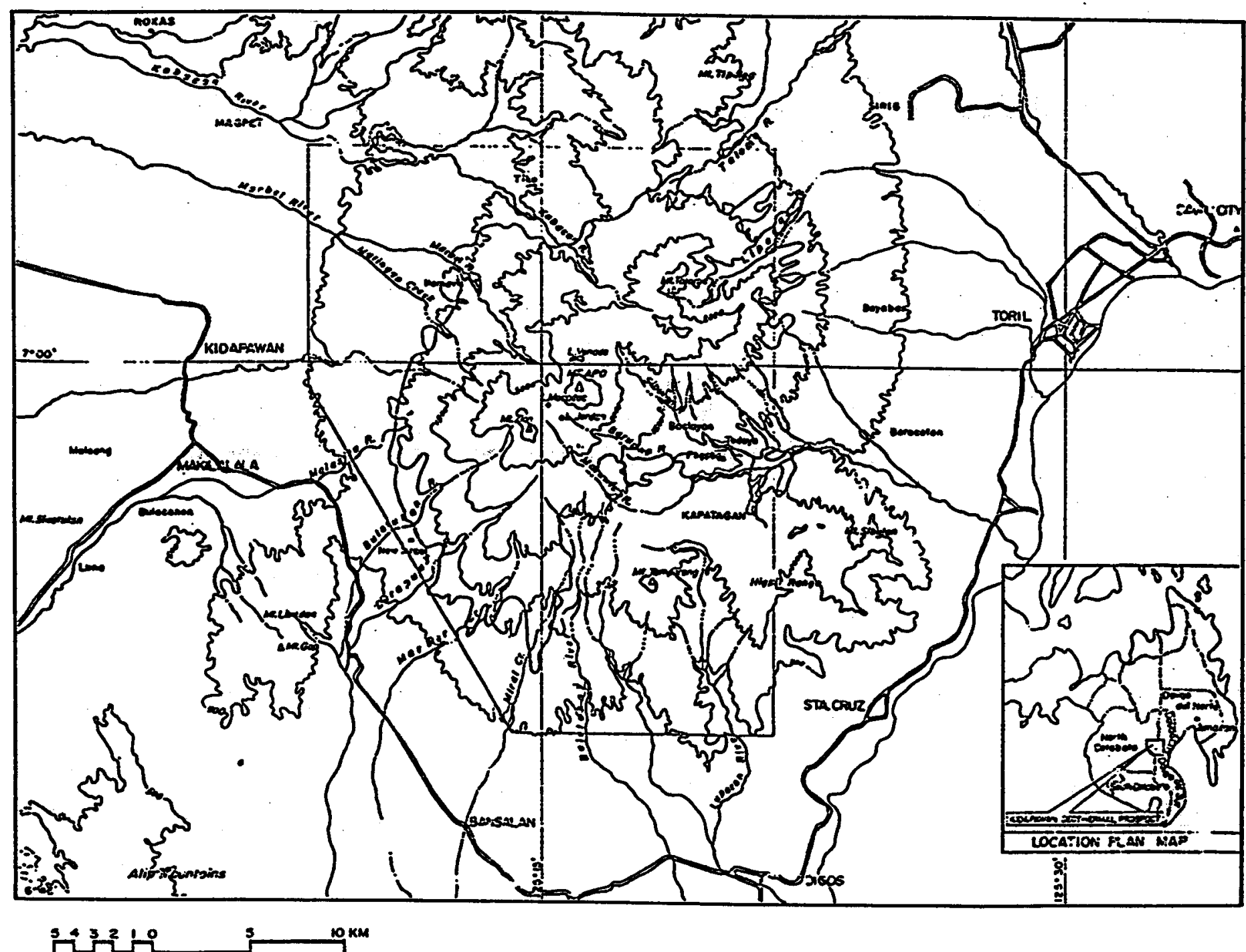

Figure 4.1: Mt. Apo Geothermal Prospect. (After Deflin and Castro, 1984). 
According to Deflin and Castro (1984), faults in the area (Figure 4.2) can be grouped into three general orientations: (1) a broad and dominant northwest system containing one or more sets with strikes between $110^{\circ}-160^{\circ}$, (2) a northeast system that trends between $20^{\circ}-50^{\circ}$, and (3) a north-south system striking $170^{\circ}-180^{\circ}$. In the vicinity of Mt. Apo, the dominant structural grain is WNW $\left(300^{\circ}-320^{\circ}\right)$ whereas near Mt. Talamo the faults have a radial pattern. The Marbel Fault Zone, located northwest of Mt. Apo (Figure 4.2) has several thermal manifestations (steaming springs and grounds) along or near the trace of the fault zone indicating that this zone of weakness acts as an important conduit for hot fluids.

\subsection{Image Amaljois}

The Mt. Apo Geothermal Prospect, as outlined on the generalized geologic map (Figure 4.2), has been located on the radar imagery (Figure 4.3). For viewing purposes, the imagery was rotated clockwise approximately 135 degrees to avoid topographic inversion. Monoscopic and stereoscopic analysis of the imagery has allowed for the inference of many faults and fault patterns (Figure 4.4).

Faults in the Mt. Apo area appear to have four general orientations:

(1) A northwest-southeast trending group that includes the Marbel and Kabacan Fault Zones and several radar-inferred faults of regional extent

(2) A north-south to northwest-southeast trending group that occurs predominantly in the central region of the geothermal area and intersects volcanic centers

(3) A group of east-west trending major faults which extend over 7 miles $(11.2 \mathrm{~km})$ in length

(4) A less dominant northeast-southwest trend 


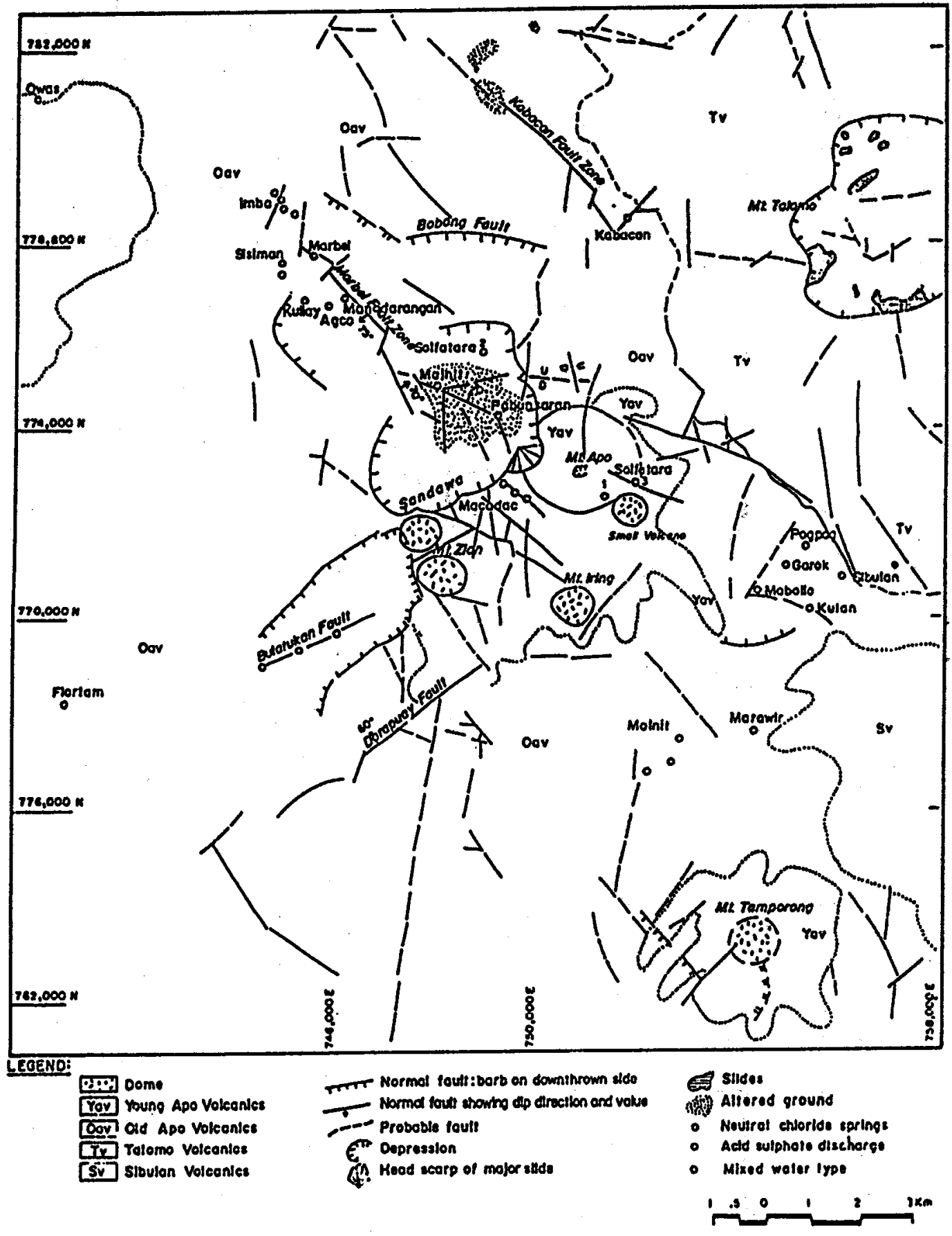

Figure 4.2: Generalized geologic map of the Mt. Apo area. Geothermal Prospect area is shown. (After Deflin and Castro, 1984). 


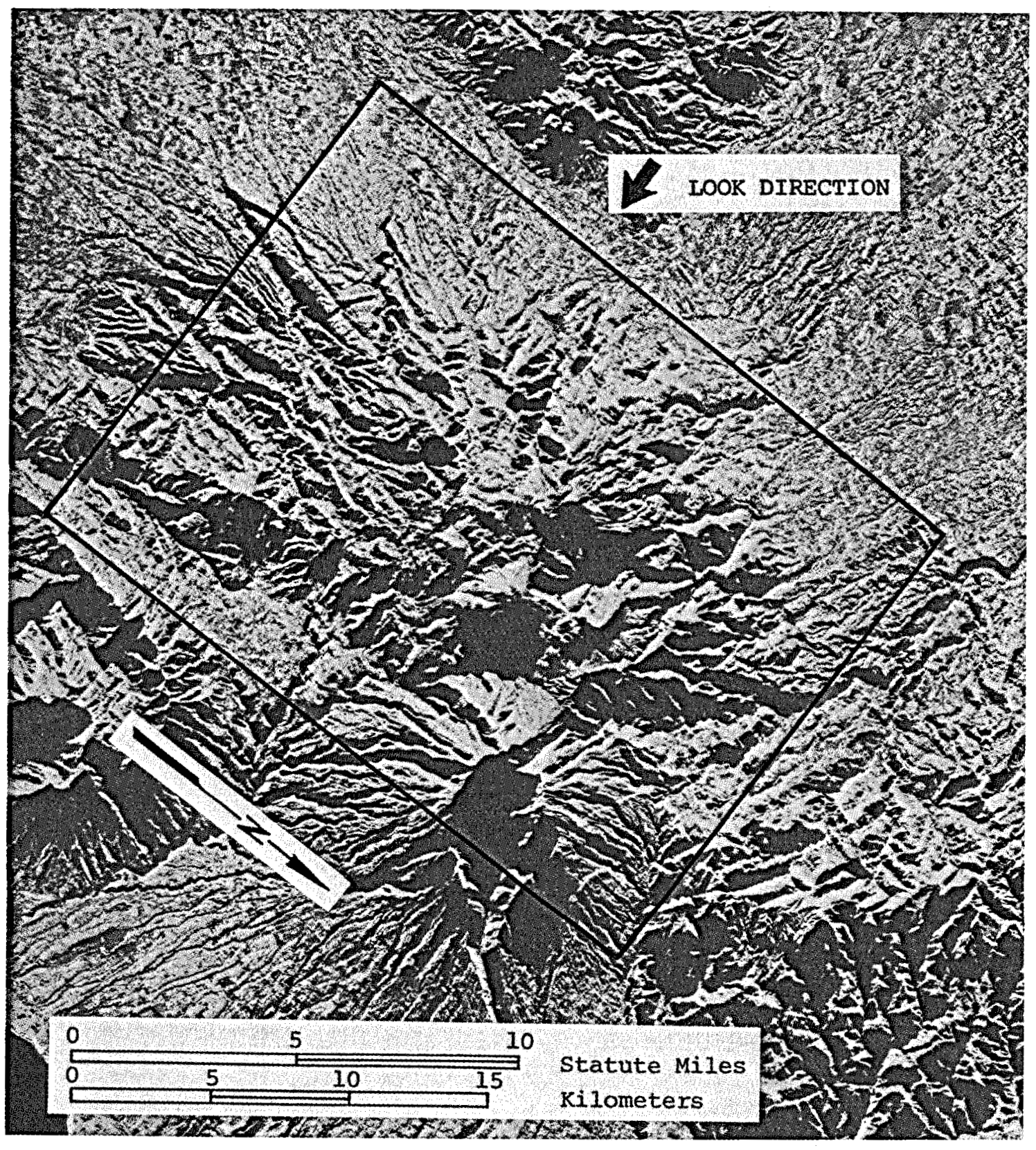

Figure 4.3: Radar coverage of the Mt. Apo Geothermal Prospect. 


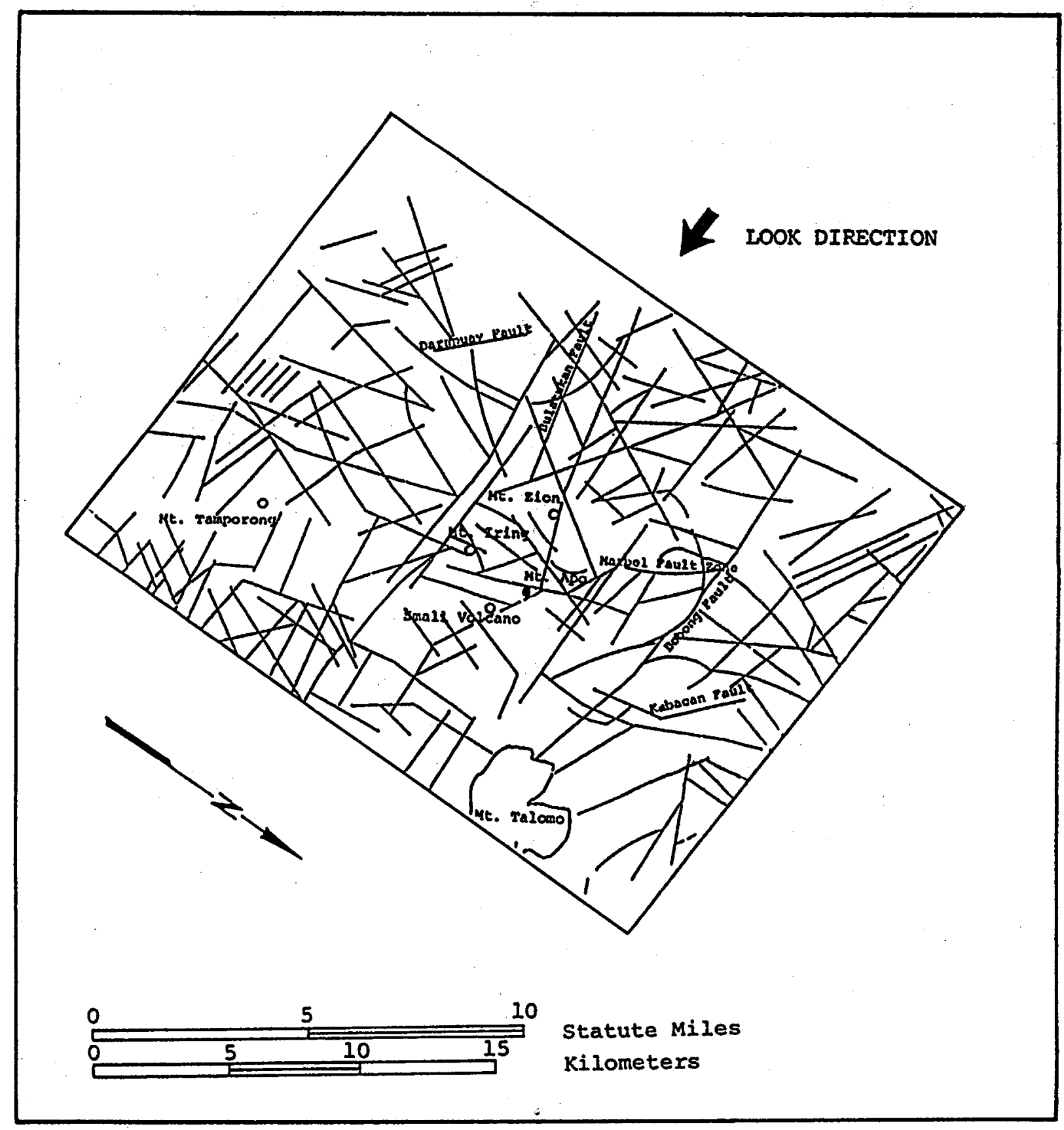

Figure 4.4: Fault interpretation of the Mt. Apo area. Geothermal Prospect area is shown. 
Fault patterns in the Mt. Apo Geothermal Prospect area can be classified into two general categories. Linear to curvilinear faults that trend perpendicular to the local surface slope may represent normal faulting which forms as a result of uplift and/or subsidence during periods of magmatic intrusion and extrusion. These faults may have a limited subsurface expression and may be confined to surface or shallow subsurface volcanic material. On radar imagery, faults in this group are commonly identified by the displacement of drainage channels or volcanic flow features that radiate from volcanic centers.

A second category of fault patterns includes faults that are regionally extensive and may define areas of subsurface structural weakness. A group of radar-highlighted, east-west trending faults characterizes this category. These faults are located southeast of the Bulatukan Fault and southeast of the Marbel Fault Zone. Fractures located on the eastern slope of Mt. Talomo and in a large Middle Miocene exposure of clastic rocks to the north display this trend. These faults as a group tend to reinforce the possibility of regionally extensive zones of structural weakness in the east-west direction. In the $M t$. Apo and Mt. Talomo areas, these faults may be the surface expression of deeper subsurface faulting in older stratigraphic units. Other such zones are identified by groups of north-south and northwest-southeast trending large scale faults. Regional faulting can be inferred from radar interpretation by recognizing abrupt textural and pattern changes that occur between rocks on adjacent sides of the fault trace. Local areas of radar shadow or high geological complexity may segment the continuous image expression of these faults.

A small group of conspicuous local faults occurs near the Sandawa Depression. A curvilinear fracture intersects the eastern end of the Bobong Fault to form a semi-circular feature around the Sandawa Depression. The 
rim of the Sandawa Depression, the Bobong Fault, and a curvilinear fault to the north of the Bobong Fault form a concentric fault pattern which partially surrounds the Sandawa Depression. The identification of this pattern suggests that the effects of the collapse event which formed the Sandawa Depression are more regionally extensive than previously mapped.

As previously discussed in Section 3.1.1, areas of radar shadow can result in the loss of interpretive information. Figure 4.5 provides an image of the Mt. Apo Geothermal Prospect area where shadowing has been reduced because of a different aircraft flight path. 




Figure 4.5: Radar imagery strip of the Mt. Apo area. Geothermal Prospect area is shown. 


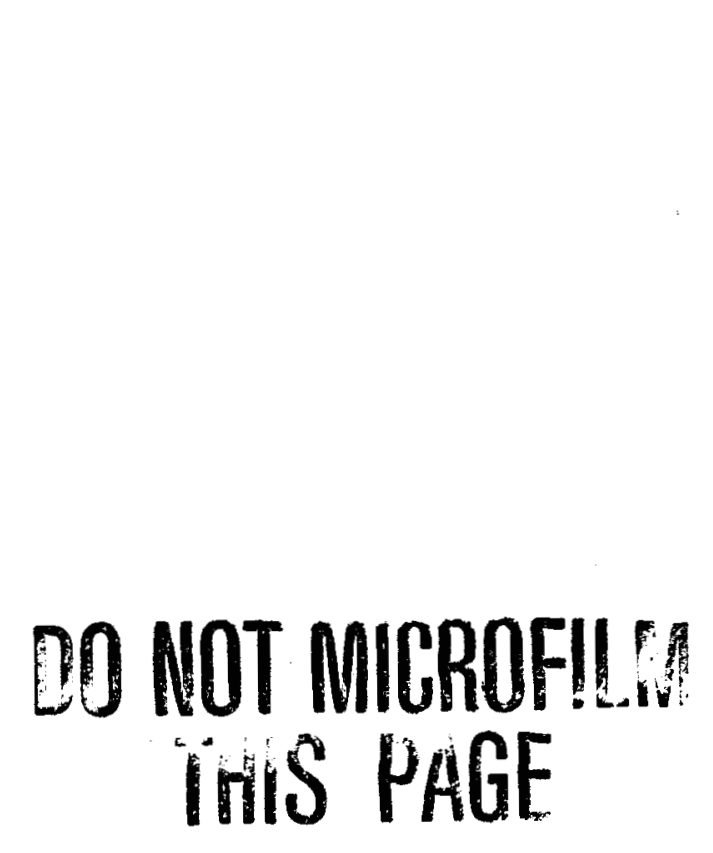

L

[

[

This page is intentionally left blank.

11

B

I

b

[

[

[

$b$

[

[

$\theta$ 


\section{SUMMARY AND RECOMMENDATIONS}

The Republic of the Philippines is not well endowed with hydrocarbon reserves, and the Government of the Philippines is anxious to spur more petroleum exploration. For both the Philippine National Oil Company Exploration Corporation (PNOC EC) and Bureau of Energy Development (BED), it has been an important goal to upgrade available geological information on various sedimentary basins in the interest of attracting foreign firms to invest or explore for hydrocarbons. The Government of the Republic of the Philippines has invited new bids from international companies to explore for oil and gas in onshore and offshore sedimentary basins. To assist the private oil industry in the evaluation of the petroleum potential of these basins, the Government, with the assistance of a loan from the World Bank, has completed a nation-wide basin evaluation program. ${ }^{3}$

The collection and interpretation of radar imagery was designed to augment and complement the existing data base prepared by PNOC EC and BED. The primary objective of the project was to further the goals of international energy development by aiding the Republic of the Philippines in the assessment of potential petroleum prospects within the areas imaged. Secondary goals were to assist the Republic of the Philippines in utilizing state-of-the-art radar remote sensing technology for resource exploration, and to train key scientists in the use of imaging radar data.

3 BED et al., 1987, Sedimentary Basins of the Philippines - Their Geology and Hydrocarbon Potential, Bureau of Energy Development, The Republic of the Philippines, Manila. 


\subsection{Radar's Value}

Because a radar provides its own source of illumination, radar images can be produced that preferentially highlight geologic structure and surface detail. Radar images so constructed provide unique information about the local geology which may not be available from other sources. Such information is needed in the Republic of the Philippines because although the region has been extensively mapped via conventional techniques, large uncertainties in the petroleum resource potential of the area still exist.

Radar's unique capabilities include:

* All weather, day-night operation

* Control of look direction and look angle for improved geological interpretation

* Wide areal coverage-synoptic view

* High resolution comparable with most remote sensing systems

* Stereo capability allows rapid formulation of geologic models

* Sensitivity to vegetation at shorter wavelengths

* Terrain texture discrimination in non-vegetated regions

* Digital capability for image enhancement and multi-sensor integration

* Radar mosaic provides an accurate base map

\subsection{Data Acquired}

Radar imagery covering roughly $60,000 \mathrm{~km}^{2}$ was acquired. These data were collected by Intera Technology, Inc., under subcontract from ARCI. ARCI provided mission planning and quality assurance for the program. 
Complete stereo coverage of five different regions was acquired. Within these five sites, the following four different sets of data were collected for hydrocarbon interpretation.

\section{Geothermal Siter \\ * Mt. Apo, Mindanao \\ * North Negros Island \\ * South Negros Island}

\subsection{Data Produced}

The final data products were (1) negative film and positive prints of each of 34 flight line strips, (2) computer compatible tapes (CCT) of each image strip, and (3) negative film and positive prints of radar mosaics of four petroleum sites at 1:250,000 scale. The Intera STAR-1 imaging radar system used to acquire these data operated at $\mathrm{X}$-band with the linear HH-polarization, and produced data representing $12 \mathrm{~m}$ resolution. The final data set represents one of the best examples of radar imagery for resource exploration available anywhere.

Interpretive data products produced include (1) geologic maps, (2) lineament maps, and (3) prospect evaluations. Development of geologic maps and prospect evaluations included extensive use of surface and subsurface data furnished by BED and PNOC EC. Thus, the final evaluation is a synthesis of all data available rather than simply that obtainable from the radar imagery itself. This is perhaps the most significant aspect of the program in that it demonstrates the use of radar as a sensor in an integrated program for hydrocarbon and geothermal exploration. The 
imagery acquired is an excellent source of data that may be used to refine exploration strategy and define areas for more detailed investigation by ground survey and seismic data acquisition. The image analysis shows numerous areas of agreement with prospects developed from other data sources such as field and geophysical surveys. In addition, a considerable number of structures and prospects were discovered, particularly in areas where other data sources were unavailable.

\subsection{Summary}

This synthesis of all available data shows radar imagery to be an excellent survey tool in an integrated multilevel exploration. The radar by itself may be used to guide acquisition of more detailed data and develop a general exploration strategy. Where other survey data such as photography or LANDSAT are available, the unique response and illumination enhancement of surface structure obtainable with radar is seen to provide additional data complementary to other survey imagery.

Important new fault and fault patterns have been identified which will provide a focus for further follow-up field and geophysical studies.

Faults and fractures that transect a geothermal reservoir may be regarded as channelways or main trunklines of a geothermal plumbing system. Therefore, a clearer picture of the regional fault/fracture patterns provided by radar interpretation could prove useful in determining permeability controls. 


\section{Ceothermal Prospectes}

* Mt. Apo Geothermal Prospect - Analysis of the radar data has led to identification of a previously unmapped east-trending fault system, and recognition of a dominant east and northwest fault system in the $\mathrm{Mt}$. Talomo region where the faulting was previously believed to be radial.

* North and South Negros Geothermal Prospects - Recognition of regional fault patterns mapped from radar will be of significant value in the planning phase for future exploratory drilling.

\subsection{Hightighto}

* The radar data and this project have improved the knowledge of stratigraphy and structure, and may provide data for updating existing geologic maps.

* The radar geologic maps produced, while important by themselves, can be used to complement existing geoscience data and can provide new map products tailored to support exploration activities.

* An important aspect of radar investigations is that reconnaissance radar images facilitate field work in remote and impassable areas.

* The baseline survey and interpretation were conducted at a scale of $1: 250,000$, but the data support increasing the scale to $1: 50,000$.

* A training course on radar interpretation and SAR fundamentals has been provided to Philippines geoscientists, and they have become enthusiastic in the potential application of using radar images for this and other important investigations such as land cover mapping (forestry or other vegetation coversl, land use mapping, hydrology, and ground-water exploration. 
* Because the imaging radar program was designed for hydrocarbon exploration in moderate relief areas, excessive radar shadow occurred in some local areas. Therefore, the Negros and Mt. Apo geothermal sites should be reflown to obtain multiple-look direction radar imagery in order to obtain complete, shadow-free, stereo coverage.

* Additional radar imagery should be acquired over a much larger region of the Philippines, especially within those areas where radar can contribute significant data to the development of an integrated exploration strategy for geothermal resources.

* Radar also should be used to explore for other natural and non-renewable resources, in addition to geothermal potential. 


\section{References}

ARCI, 1988, Radar Imagery Interpretation to Assess the Hydrocarbon Potential of Four Sites in the Philippines, ARCI TR 8701-101, Arkansas Research Consultants, Inc., November 17, 1988.

Alcaraz, A. P., 1984, Application of Structural Geology in the Puhagan Fault System Study, Southern Negros Geothermal Field, The Philippine Geologist, Vol. XXXIII, No. 4, pp. 2 - 16.

Alincastre, R. S., 1983, Geology of Northern Negros Geothermal Project Mambucal, Saray and Hagdan Areas, PNOC-EDC Report, 17 p.

Barnett, P. R., O. S. Espanola, and H. P. Ferrer, 1984, A Review of Philippine Geothermal Exploration StrategJ, The Philippine Geologist, Vol. XXXIII, No. 4, pp. $17-25$.

Defline, F. G., and C. C. Castro, 1984, Mt. Apo Geothermal Project First Stage Exploration and Evaluation, PNOC-EDC Internal Report, 71 p.

Harper, R. T., and E. M. Arevalo, 1983, A Geoscientific Evaluation of the Baslay - Dauin Prospect, Negros Oriental, Philippines, PNOC EDC Technical Bulletin, Vol. I, No. 2, pp. 78 - 94.

Seastres, J. S., Jr., 1982, Subsurface Geology of the Nasuji - Sogongon Sector, South Negros Geothermal Field, Philippines, PNOC-EDC Technical Bulletin, Vol. I, No. 1, pp. 21 - 34. 